Discussion Papers
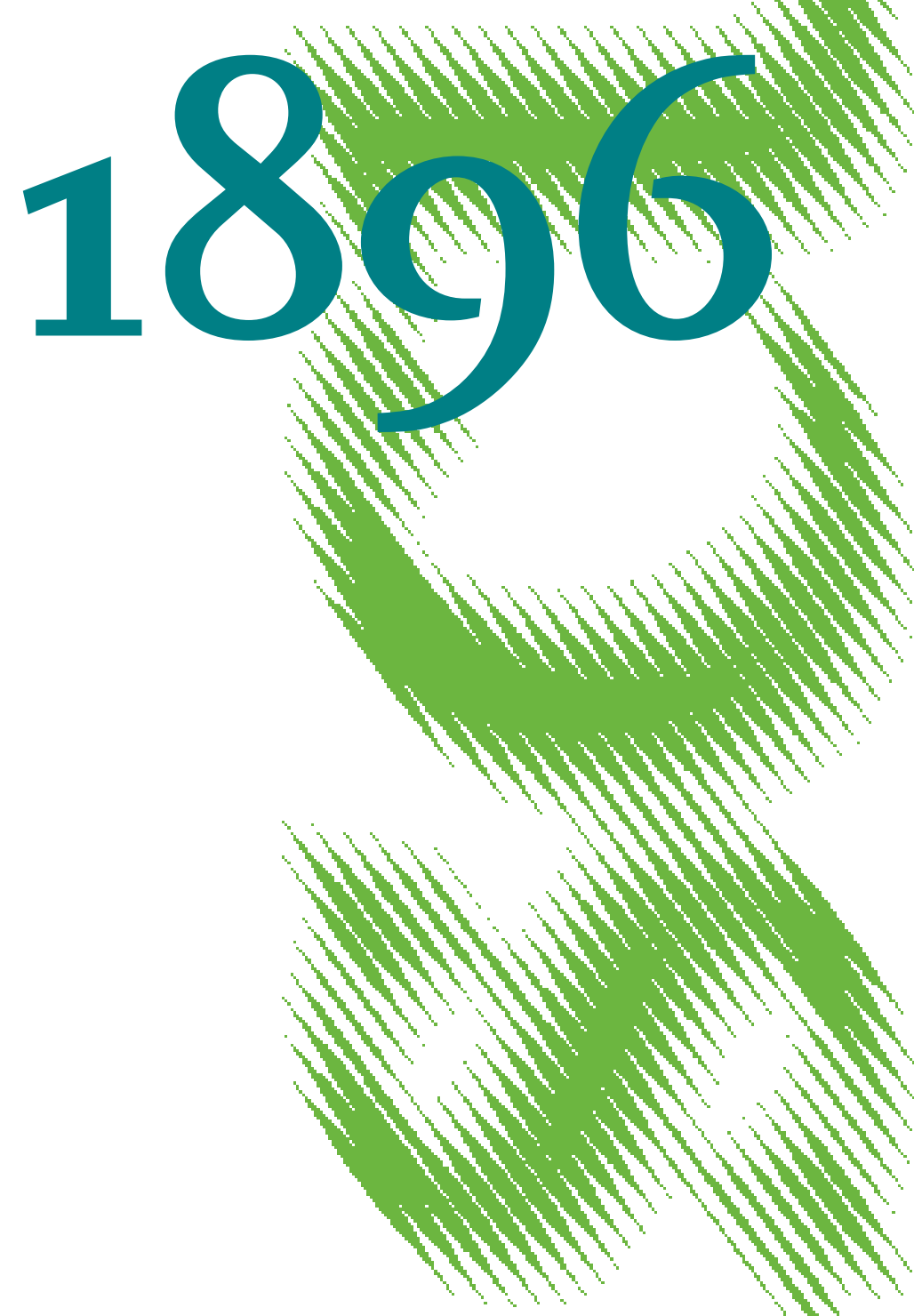

The Impact of the Length of Schooling on the Timing of Family Formation 
Opinions expressed in this paper are those of the author(s) and do not necessarily reflect views of the institute.

IMPRESSUM

(C) DIW Berlin, 2021

DIW Berlin

German Institute for Economic Research

Mohrenstr. 58

10117 Berlin

Tel. +49 (30) $89789-0$

Fax +49 (30) $89789-200$

http://www.diw.de

ISSN electronic edition 1619-4535

Papers can be downloaded free of charge from the DIW Berlin website:

http://www.diw.de/discussionpapers

Discussion Papers of DIW Berlin are indexed in RePEc and SSRN:

http://ideas.repec.org/s/diw/diwwpp.html

http://www.ssrn.com/link/DIW-Berlin-German-Inst-Econ-Res.html 


\title{
The impact of the length of schooling on the timing of family formation ${ }^{\text {th }}$
}

Josefine Koebe*, Jan Marcus

January 2021

\begin{abstract}
Individuals typically traverse several life phases before forming a family. We analyse whether changing the duration of one of these phases, the education phase, affects the timing of marriage and childbearing. For this purpose, we exploit the introduction of short school years in Germany in 1966-67, which compressed the education phase without affecting the curriculum. Based on difference-in-differences regressions and German Micro Census data, we find that earlier graduation due to short school year exposure affects the timing of marriage for individuals in all secondary school tracks and shifts forward the birth of the first child mainly for academic-track graduates. This highlights that education policies might not only affect family formation through human capital accumulation, but also through changing the duration of earlier life phases. This is important as not only age at marriage and first birth increases in many countries, but also the duration of the education phase.
\end{abstract}

Keywords: family formation, instruction time, fertility, marriage JEL: I26, J12, J13, J24

\footnotetext{
We are thankful for helpful comments from Kamila Cygan-Rehm, Nathalia Danzer, Daniel Kemptner, Michael Kvasnicka, Analia Schlosser, Hannes Schwandt, Thomas Siedler, Helena Skyt Nielsen, and Matthias Westphal.

*Corresponding author.

Email addresses: jkoebe@diw.de. University of Hamburg \& DIW Berlin (Josefine Koebe), jan.marcus@uni-hamburg.de. University of Hamburg \& DIW Berlin (Jan Marcus)
} 


\section{Introduction}

Almost all industrialized countries see a secular trend toward postponing family formation to later ages (OECD, 2019) - with important economic consequences. Postponed childbearing decreases - all else equal - the number of children born per year, putting the funding of social security systems under pressure (e.g. Billari et al., 2006). The timing of marriages and first births also have large impacts on other economic decisions, including on savings and the spacing of subsequent births (Díaz-Giménez and Giolito, 2013, Hodsdon and Marini, 2019). Additionally, medical costs increase with later child births due to adverse health effects (e.g. Gustafsson, 2001; Myrskylä and Fenelon, 2012) and because fecundity declines with age (Larsen and Vaupel, 1993) making fertility treatments and involuntary childlessness more likely.

This paper contributes to our understanding of whether and how policies that alter the duration of specific life phases can act as drivers of marriage and fertility timing. In most developed countries, individuals traverse several life phases in a rather strict order before they form a family (Blossfeld and Rose, 1992, Billari et al., 2000, Lutz and Skirbekk, 2005; Huinink and Kohli, 2014). Primary and secondary schooling precede tertiary education, education phases typically precede labor market entry and labor market entry typically precedes family formation. Given the sequencing of life phases, there is surprisingly little research on the consequences of extending or reducing one of these phases. However, analyzing the duration of earlier life phases is not only relevant in explaining later childbearing and decreasing fertility rates, but it may also offer a potential lever for public policies.

We study a policy change in Germany that reduced the length of the education phase. This policy allowed entire cohorts to graduate from secondary school about eight months earlier - with the same degree and the same curriculum. Before the reform, the school year started in spring in some German states and in fall in other states. After a policy change to harmonize the education system across states, school started in fall in all states. States achieved the shift of the school year start from spring to fall by the introduction of so-called short school years (Kurzschuljahre), in which two school years were put in about 16 calendar months in 1966/67. Pischke (2007) analyses this reform as well. He finds that the short school years did not have any negative impacts on human capital acquisition as it reduced neither labor income nor employment prospects; a finding that we replicate in this paper. Further, Braakmann (2010) shows that there are no effects of the reform on health outcomes. Similar to Pischke (2007) and Braakmann (2010), we exploit this reduction of the length of schooling in a difference-in-differences framework, where we compare cohorts before and after the reform in affected states with the same cohorts in states that did not 
introduce short school years. We pool several cross-sections of the German Micro Census, a one percent sample of the German population, to study the effect of this reform on the timing of marriage and fertility.

We find that earlier graduation due to short school year exposure affects the timing of marriage and child birth. More specifically, we show that the short school years increase the probability to be married eight years after the normal graduation age by about 3.7 percentage points (pp) for individuals in the middle track and by about $4.1 \mathrm{pp}$ for individuals in the academic track (compared to sample means of 43 and 37 percent, respectively). Moreover, individuals in the academic track are also $3.2 \mathrm{pp}$ more likely to have a first child eight years after graduation (compared to a sample mean of 22 percent). These effects do not only hold eight years after graduation but also five years after graduation and up to ten years after graduation. However, the effects fade over time, indicating that the short school years affected the timing of marriage and parenthood, but not the probability to ever marry or become a parent. We further show that the obtained effects are driven by both males and females, as well as that the reform affected also the probability to have a second child within the first ten years after graduation for individuals in the academic track. Our findings provide evidence that policies that change the duration of specific life phases can affect family formation.

Our study contributes to the literature on the relationship between education and family formation. There is ample evidence that higher levels of education are associated with later childbearing (see, e.g., Skirbekk, 2008) and marriage (see, e.g., Jejeebhoy, 1995 , Oppenheimer, 1997) in various countries and time periods. The literature discusses mainly lock-in and human capital effects as mechanisms why education can causally affect family formation. The lock-in effect means that individuals are less likely to marry and give birth while in school (Black et al. 2008), e.g. due to a high degree of economic dependence on the parents or the incompatibility of child rearing and acquiring education (Blossfeld and Rose, 1992). The human capital effect relates to the idea that education increases labor market opportunities and, thereby, the opportunity costs of children (Becker, 1981).1. While the former mechanism relates only to family formation during education, the latter mechanism looks at family formation after the education phase.

In order to empirically test whether the negative education-fertility relationship is causal, many empirical studies capitalize on unintended fertility consequences induced by educational reforms. Most studies use exogenous variation from laws changing age at school entry or

\footnotetext{
${ }^{1}$ Becker's theoretical approach targets marriage and fertility behavior alike, as his approach regards child production and rearing as the main purpose of marriage. He formulates the argument of sex-specific division of labor as an incentive to enter into marriage and also with respect to the decision to have children.
} 
compulsory schooling reforms. The effect of education using school entry rules is found to be more profound with respect to teenage pregnancies (Black et al., 2011; Tan, 2017), while McCrary and Royer (2011) find little evidence for school entry policies affecting age at first birth. Almost all studies on compulsory schooling reforms provide evidence that longer educational attainment leads to postponement of first births (see, e.g., Black et al., 2008; Monstad et al., 2008; Silles, 2011; Cygan-Rehm and Maeder, 2013: Grönqvist and Hall, 2013). The empirical evidence regarding the effect on completed fertility is more mixed. While some studies find that education decreases completed fertility (see CyganRehm and Maeder (2013); Fort et al. (2016) for England), other studies show that education has no effect on completed fertility (Monstad et al. (2008); Fort et al. (2016) for Continental Europe). Furthermore, Devereux and Tripathi (2009) find that increasing the length of compulsory schooling also leads to higher ages at first marriage. There are also some studies that exploit institutional changes at higher levels of the educational system. Currie and Moretti (2003) and Kamhöfer and Westphal (2019) use college expansions in the U.S. and Germany, respectively, as an instrument for education. Currie and Moretti (2003) find that higher educational attainment reduces completed fertility and Kamhöfer and Westphal (2019) find that increasing education affects the timing of childbirth and reduces the probability of becoming a mother.

We contribute to the literature on the relationship between education and family formation by proposing a third causal mechanism, a duration effect. Education might affect family formation since it affects the timing of subsequent life phases (in particular, labor market entry), which individuals typically traverse before forming families. It is very difficult to separate this duration effect from the human capital effect and, actually, all studies that rely on post-education effects of compulsory schooling reforms and college expansions look at the combined human capital and duration effect. The short school years are, therefore, a particular policy reform as (i) this reform allowed for earlier graduation from school without affecting the curriculum; and (ii) previous empirical studies find no evidence that this reform had adverse effects for human capital acquisition (Pischke, 2007; Braakmann, 2010). The idea of the duration effect of education is also in line with the finding of Humlum et al. (2017) that delayed college enrollment leads to the postponement of marriages and childbearing.

Our study also contributes to the literature on policies that affect family formation by highlighting the importance of unintended consequences of policies that reduce or extend specific life phases. While pro-natalist and pro-marriage policies are highly controversial (see, e.g., Cherlin, 2003), it is important to know whether and how existing policies affect family formation, irrespective of the normative standpoint. Many empirical fertility studies 
focus on the impact of specific family policies including direct financial transfers like child allowances and fiscal incentives (e.g., Björklund, 2006) as well as work-related family policies like parental leave benefits (e.g., Lalive and Zweimüller, 2009, Cygan-Rehm, 2016, Kluve and Schmitz, 2018; Raute, 2019) and child care availability (e.g., Rindfuss et al., 2010, Mörk et al. 2013; Bauernschuster et al., 2016). In her literature review, Gauthier (2007) concludes that several family policies are found to increase fertility but that the magnitude of these effects is small. There are also several studies that deal with the effect of specific policies on the marital status. These policies almost exclusively focus on financial incentives; for instance, tax penalties Alm and Whittington, 1997; Baker et al., 2004) and benefits (Fink, 2020), welfare expansion (Halla et al., 2016), the elimination of survivors insurance (Persson, 2020), and cash-on-hand marriage subsidies (Frimmel et al., 2014). While the majority of these studies provide evidence that financial incentives affect the timing of marriage, only some find effects on the probability to ever marry.

Our study emphasizes that family formation is not only affected by pro-natalist or promarriage policies, but also as a side effect of other policies, e.g., policies that alter the duration of the education phase. This is not only important for policymakers to keep in mind when discussing education reforms, but it also might offer a tool for those who would like to change the timing of family formation. Further, our study points out that the consequences for family formation should be considered when discussing policies that affect the duration of specific life phases. This is important, for instance, in current debates about the European Bologna reform shortening the time to a fist university degree (Hahm and Kluve, 2019), the suspension (and re-introduction) of compulsory military service in several countries (Imbens and van der Klaauw, 1995; Bauer et al., 2012), the German G8 reform shortening the schooling phase (Huebener and Marcus, 2017, Marcus and Zambre, 2019), and the general education expansion occurring in many developed and developing countries.

Therefore, our study contributes to both the literature on the relationship between education and family formation as well as the literature on policies that affect family formation. An additional contribution that this study has to offer is the detailed compilation of dates (and primary sources) for several relevant education reforms in West Germany, where there is some ambiguity in the previous literature. These reforms do not just include the short school years but also regulations regarding school entry ages, the beginning of the school year, and compulsory schooling. The collection of reform dates and law sources allows for isolating the short school year reform from previous changes of the school year start and assigning the short school years more precisely compared to previous studies. This framework can also be used by other researchers. 
The remainder of the paper is structured as follows: Section 2 describes the institutional setting and Section 3 the data, while Section 4 outlines the empirical strategy. This is followed by the main results in Section 5, sensitivity analyses in Section 6 and additional results on gender differences, longer time horizons, and subsequent births in Section 7. Section 8 concludes.

\section{Institutional background}

We study a policy change in West Germany in 1966/67 that reduced the length of the education phase by introducing short school years (SSY). These short school years compressed two school years into 16 calendar months. The SSY were introduced in an effort to harmonize the start of the school year across states.

In October 1964, the Ministers of Education of the West German federal states decided, in what is known as the Hamburg Accord (Hamburger Abkommen), that the school year would begin in the fall in all eleven states (Froese, 1969, pp.327-323). Before this decision, Easter marked the begin of the school year in most states, while in Bavaria the school year began in fall ${ }^{2}$

Seven states (Baden-Württemberg, Bremen, Hesse, North Rhine-Westphalia, RhinelandPalatinate, Saarland, Schleswig-Holstein) achieved the shift of the school year start by introducing so-called short school years (Kurzschuljahre), in which two school years were put in about 16 calendar months (see Helbig and Nikolai, 2015, p.70-73): The first SSY started on April 1, 1966, and ended on November 30, 1966, while the second SSY year started on December 1, 1966, and ended on July 31, 1967. Due to these short school years, affected individuals graduated about two-thirds of a school year earlier (or about eight months of calendar time), but with the same degree and curriculum taught. ${ }^{3}$

Three states did not introduce SSY: Bavaria (where schools already started in fall before the Hamburg Accord) as well as Hamburg and West-Berlin. The two latter states opted for

\footnotetext{
${ }^{2}$ This was actually not the first change of the start of the school year: During the Nazi regime, in 1941, the start of the school year was shifted to a common start in fall (see Reichsgesetzgebung in 1941 in Table B.12, after the Second World War most federal states successively switched back to a starting date at Easter (KMK, 1962). In February 1955, the states' Ministers of Education proclaimed Easter as a uniform start of the school year across all federal states in the so-called Düsseldorf Accord (Düsseldorfer Abkommen) (Froese, 1969, pp.307-311). However, the Bavarian parliament voted against the implementation of this resolution. As a result, children in Bavaria have started their school year in the fall ever since 1941. For a comprehensive collection of schooling laws related to the shift of the start of the school year in the German federal states, see Appendix B.

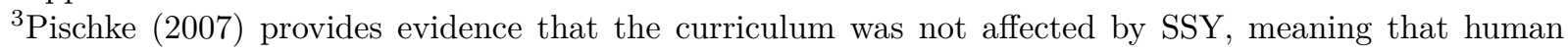
capital acquisition is likely to be unaffected.
} 
a long school year to transition to the uniform start in fall. In both states, students who were in their graduating year and had once begun their school career with a school start at Easter also graduated in March. Hence, students from Berlin and Hamburg attended the regular amount of time required without any school year reductions despite the school year transition to a start in the fall.

In West Germany, students in all states opt for one of three secondary school tracks after four years of joint primary schooling at around age ten (see Dustmann et al. (2017) for a detailed synopsis on the German tracking system): basic (Hauptschule, grades 5-8/9), middle (Realschule, grades 5-10), or academic track (Gymnasium, grades 5-13). Generally, the shifting of the school year start in 1966/67 affected students in primary school as well as in all secondary school tracks. Several states changed compulsory schooling regulations during our observation period from eight to nine years (Backhaus, 1963 ; Leschinsky and Roeder, 1980, Petzold, 1981). These changes mainly affect students in basic track and we discuss compulsory schooling regulations in more detail in Appendix B and potential consequences for our estimates in the robustness section (Section 6).

Lower Saxony was the only state that differentiated between tracks in terms of SSY exposure. Basic track students were unaffected by SSY, as for graduating classes their short school year losses were added in their final year. Depending on their school starting cohort, middle track students were ambiguously affected by SSY due to changing regulations with respect to the graduating classes in the years after the short school years ${ }^{4}$ while academic track students were fully affected by the policy reform without any school year extensions for graduating classes.

Pischke (2007) assigns the seven states that introduced short school years to the treatment group, while he assigns the three states that did not introduce short school years to the control group. Lower Saxony is partly assigned to the treatment group and partly due to the control group, depending on the institutional details described above.

\section{Data}

Our analysis uses data from the German Micro Census (RDC, 2019), a one percent sample of all German households. Once drawn for the survey, participation is mandatory and, hence,

\footnotetext{
${ }^{4}$ As described in more detail by Pischke (2007), students entering their final year with the first SSY were exposed to one SSY, the next three cohorts starting their final year in December 1966 through August 1968 were exposed to two SSY. The next six cohorts, however, who were in their last school year from August 1969 to August 1974 were subject to school year extensions such that they graduated from March 1971 until March 1976 after the regular amount of schooling of 10 years. See Table B.7 for an overview.
} 
selective non-response and attrition is not a concern. We use the scientific use file, a 70 percent random sample of the data, and the 18 waves from 1976 to 2003 $5^{5}$ The data set is well-suited for our analysis as it contains rich information on family structure, marriage, and education. Importantly, each of the 18 waves includes about 300,000 to 400,000 individual observations in the West German states, providing a large number of observations in target cohorts and allowing for a precise estimation of reform effects.

\subsection{Outcome measures}

Our main outcome variables relate to the timing of marriage and parenthood. More specifically, we look at the probabilities to be married and to have a child in or before period $p \in\{5,8,10\}$, i.e., five, eight, and ten years after the regular graduation age. More formally, the outcome variables $Y^{e, p}$ are defined as

$$
Y^{e, p}= \begin{cases}1 & \text { if } e \text { in } t \leq p \\ 0 & \text { otherwise }\end{cases}
$$

where $t \in[1,10]$ indicates the time (measured in years after the regular graduation age) the event $e \in\{$ marriage, parenthood $\}$ took place. The regular graduation age refers to the age at which individuals usually graduate from a specific track, i.e. in the absence of short school years: age 15 when in basic track, at age 16 when in middle track, and at age 19 when in academic track. In further analyses, we also look at other time intervals.

We construct the marriage outcomes based on the wedding year of the current marriage. While also divorced and widowed individuals are asked about the year of their last marriage, there is no information on whether the current marriage is also respondents' first marriage. This introduces measurement error in the dependent variable. However, there is no reason to assume that this measurement error is related to the SSY introduction. Further, we limit the extend of measurement error by considering only the information of respondents up to a specific age (see below).

There is also measurement error in the fertility outcomes. In our data, individuals are not directly asked about their biological children. However, birth information is available for all children in the household. Based on this information, we calculate the parents' age at the birth of their first child as the difference between the year of birth of the oldest child in the household and that of the parents. This procedure induces measurement error in households

\footnotetext{
${ }^{5}$ The Micro Census was conducted in 1976, 1978, 1980, 1982, 1985, 1987, 1989, 1991, 1993, and in all years from 1995 to 2003. 2003 is the last Micro Census wave in our main sample as we focus on respondents up to age 39 and on birth cohorts up to 1964.
} 
in which the oldest child died or left the household as well as in households that adopted the oldest child. This measurement error is of particular concern as older children are more likely to move out of the household. We, therefore, restrict the analyses to individuals who are up to 39 years at the time of the interview, as it is less likely they have children who already left the household. This cut-off below 40 is recommended by Krapf and Kreyenfeld (2015), who compare the number of children based on this procedure with the number of biological children. In the robustness section, we show that our results are insensitive to alternative cut-off ages.

While we also look at the birth of a second child, we abstain from analyzing higher order parities or completed fertility as we only observe children living in the household. For these outcomes, the measurement error would be much larger. In our data, we face a trade-off between looking at longer time horizons and systematic measurement error in our outcome variables due to children moving out of the household. By looking at outcomes up to five, eight, and ten years after graduation, the measurement error in our outcome variables will not be very large. Further, the timing of family formation is also relevant from an economic perspective because it affects many other economics decisions and because later childbearing means later labor market entry for the children, putting social security systems under pressure.

\subsection{Treatment assignment}

We basically follow Pischke (2007) in assigning the treatment variable and restricting the sample, but make some small changes to allow for a more precise assignment of the length of schooling. ${ }^{6}$ SSY exposure depends on three characteristics: the federal state of students' school location, students' school starting cohort, and the secondary school track (see Section 2). In principle, SSY affected all students in treatment states who were enrolled in primary or secondary school in 1966/67. However, at a given point in time, additional cohorts are enrolled in academic and middle track compared to the basic track, as the basic track caters grades 5-8 or 5-9,7 the middle track grades 5-10, and the academic track grades 5-13.

Figure 1 is a stylized graph that visualizes SSY exposure in treatment states and the resulting years spent in school until graduation, depending on individuals' secondary school track and school starting cohort. A student entering primary school in a treatment state in 1952 had already left secondary school by the start of the first SSY in 1966, irrespective of the

\footnotetext{
6 Pischke (2007) finds that SSY exposure had no adverse long-term effect on human capital acquisition and we can replicate this finding using his sample restrictions (see Table A.1 in Appendix A).

${ }^{7}$ Several states increased the number of years of compulsory schooling from eight to nine see the discussion in Section 6 and Appendix B.
} 
attended track. The same holds for the school starting cohorts 1953 and 1967-1970. For the school starting cohorts 1954-1958, however, the choice of secondary school track matters for SSY exposure. For instance, students from the 1957 school starting cohort were exposed to two SSY in academic track, while they were exposed to only one SSY in middle track and no SSY in basic track. For school starting cohorts 1959-1966, students in all school forms were exposed to two SSY and, hence, graduated two-thirds of a school year earlier, while the four school starting cohorts 1964, 1965, 1966 (first SSY), and 1966 (second SSY) were all exposed to the reform during primary school. In sum, SSY exposure depends on federal state, school starting cohort, and secondary school track; consequently, we assign the treatment variable based on these three characteristics.

Our treatment variable takes on the value 1 if an individual was exposed to two SSY and the value 0 if an individual was not exposed to SSY. Individuals who were in the last year of secondary school when SSY were introduced as well as individuals who started primary school with the second SSY were only exposed to one SSY. For these individuals, the treatment variable is set to 0.5 .

When assigning the treatment variable, we must deal with several challenges due to the nature of the Micro Census data. First, we only have information on the current state of residence, but not on the state an individual went to school. This is a common issue when working with the Micro Census, but residential mobility across states is very low in Germany and the current state of residence is found to be a good proxy for the state in which an individual went to school (see, e.g., Pischke, 2007, Pischke and von Wachter, 2008, Jürges et al., 2011). We further limit the extent of this measurement error by considering only respondents below the age of 40 .

Second, retrospective information on the attended school track in a given year is not provided in the Micro Census. However, switching tracks and degree upgrading as adults is not very common in the analyzed cohorts in Germany (Dustmann et al. 2017). 8 This is another common issue when working with this data set and we follow the procedure of previous studies (see, e.g., Pischke, 2007; Pischke and von Wachter, 2008; Jürges et al., 2011, Cygan-Rehm and Maeder, 2013), assigning the school track based on information on the highest secondary school degree obtained.

Third, information on grade repetition is not available. Therefore, we mistakenly assign grade repeaters from the last cohort before the SSY introduction to the control group, even though they actually experienced SSY due to their grade repetition. This misassignment of

\footnotetext{
${ }^{8}$ We limit also the extent of this measurement error by considering only respondents who participated in the Micro Census before age 40.
} 
the treatment variable results in a (small) downward bias. Our results are robust to excluding the last pre-treatment cohort (see Section 6).9

Fourth, the data lacks information on the exact month of birth, which would allow a more precise assignment of students' school starting cohorts based on the respective legal schoolstarting age cut-off in each federal state at the time (see Appendix B for a comprehensive collection of educational laws on school-starting cut-off rules for all West German states). The Micro Census data provide only information on the season of birth, that is, whether individuals were born between January and April or between May and December. In most federal states, the age cut-offs coincide to a large extent with this season of birth information. While Pischke (2007) and Braakmann (2010) assign the treatment indicator only based on the year of birth and assume a school start in the year the child turns seven, we exploit the season of birth information to reduce misassignment of actual treatment status 10

\subsection{Sample restrictions}

We restrict our analysis to German respondents in private households in West Germany and exclude individuals who obtained their school degree in East Germany. We impose several additional sample restrictions and, in Section 6, we show that our conclusions also hold if we apply different constraints. In our main analysis, we consider cohorts starting school between 1952 and 1970. This translates to using birth years ranging from 1945-1964. However, we exclude school starting cohorts 1964, 1965, and both school starting cohorts in 1966 in our main specification. These cohorts were exposed to SSY during primary school and Pischke (2007) shows that these cohorts have a lower probability of enrolling in either the middle or academic tracks. Hence, for these cohorts, the secondary school track is endogenous. The remaining birth cohorts in our sample made their track choice before the SSY introduction. While Pischke (2007) and Braakmann (2010) use birth cohorts from 1943-1964, we focus on a slightly smaller window of cohorts (1945-1964). The main reason for this is that, in several states, the birth cohorts 1943 and 1944, thus, school starting cohorts 1950 and 1951, were affected by previous changes of the start of the school year from fall to Easter in line with the Düsseldorf Accord. However, for the federal state of Saarland, narrowing the sample window does not allow for isolating the impact of the SSY, as more than the first two cohorts

\footnotetext{
${ }^{9}$ Further, Pischke (2007) shows that SSY exposure increases grade repetition among cohorts who were exposed in primary school. We exclude these cohorts from our main analysis (see below).

${ }^{10}$ Our results are robust to assigning the treatment based only on the year of birth (see Section 6.
} 
were affected by altered length of schooling (see also footnote 2, Figure B.1 and Tables B.1. B.11).11. Therefore, we exclude Saarland from our main analysis.

We also impose a restriction on the respondents' age. We only consider the information of respondents ten to twenty years after regular graduation.12 We impose the lower age limit of ten years after graduation in order to have the same sample for all outcome variables irrespective of the considered time window after graduation. We apply the upper age limit of twenty years after graduation to reduce measurement error in our outcome variables due to second marriages and children who have already moved out (see the discussion above). Twenty years after graduation also means that for individuals in the academic track, the maximum age of respondents is 39 , which is also below 40, the age cut-off recommended by Krapf and Kreyenfeld (2015). Consequently, basic track students' reporting age is between 25 and 35 years, middle track students' between 26 and 36 years and academic track students between 29 and 39 years of age. Our sample restrictions lead to the final estimation samples of 203,501 observations in basic track, 98,448 in middle, and 109,199 in academic track, a grand total of 411,148 observations.

\subsection{Descriptive statistics}

Table 1 reports sample summary statistics by track. Several points are worth noting. First, the share of females is lower in the academic track. This is not a methodological artifact, rather it is a sign of discrimination against women in the examined cohorts. Second, while the samples in all three tracks comprise the same school starting cohorts 1952-1970, the average birth year differs between the tracks. This is due to the general trend of increasing educational attainment over time: Whereas 59 percent of students from the 1952 school starting cohort graduated from basic track, by the end of our sample period in 1970, this share had decreased to 37 percent. Third, the age difference between the tracks is a result of the sample restriction to only consider the answers of respondents ten to twenty years after graduation. Fourth, at the time of the interview, $22 \%$ of individuals in the basic track had not married, while this share is $25 \%$ for the middle, and $32 \%$ for the academic tracks. ${ }^{13}$

\footnotetext{
${ }^{11}$ Saarland was last to implement the common start of the school year at Easter in 1957 and, hence, had to switch start of the school year again within a shorter time period. Our results are robust to including Saarland (see Section 6 ).

${ }^{12}$ We drop 879 observations with births before age 15 (accounting for 0.2 percent of the final sample). We assume that these young ages rather relate to classification errors as we only observe children currently living in the household - and not necessarily only biological children.

${ }^{13}$ Note that about $4-5 \%$ of individuals in our sample are divorced. However, we can correctly assign the year of marriage for them as the Micro Census also asks both divorced and widowed individuals about the year of their marriage.
} 
Among individuals who are married (or who have been married), the average age at marriage is clearly lower for individuals in the basic track (22.7 years) than in the middle (24 years) or academic (26.7 years) tracks. Similar differences across tracks can be obtained for the age at birth of the first child. Fifth, at the time of the interview (i.e. ten to twenty years after graduation), the share of individuals without children is ten percentage points higher in the academic track than in the basic track.

Next, we examine the patterns of family formation between the tracks in more detail. Figures $2 \mathrm{a}$ and $2 \mathrm{~b}$ show that the higher the school track, the lower the probability to be married or to have a first child at any given age.14 This observation is in line with both the human capital effect of education and the duration effect of education. ${ }^{15}$ It is striking that the differences between individuals in basic and middle tracks are smaller compared to the differences between middle and academic tracks. This reflects that the length of the education phase is more similar between individuals in basic (eight to nine years) and middle tracks (ten years) than individuals in the academic track (thirteen years). Moreover, the graphs are also in line with the lock-in effect of schooling. Individuals in the academic track are clearly less likely to be married or to have a first child before the age of 19, the age when they finish secondary education. When accounting for the different lengths of secondary schooling (as in Figure 2c and Figure 2d, the differences between the tracks are still existing, which is in line with the human capital effect of education. However, the differences get much smaller, providing suggestive evidence for the duration effect of education.

\section{Empirical strategy}

To identify the effect on family formation of shortening the education phase through the introduction of short school years, we estimate the following difference-in-differences (DiD) equation separately for each track $J$, with $J \in\{$ basic, middle, academic $\}$ :

$$
Y_{i s c}^{J}=\beta^{J} S S Y_{s c}^{J}+\gamma_{s}^{J}+\lambda_{c}^{J}+X_{i s c}^{\prime} \delta^{J}+\varepsilon_{i s c}^{J}
$$

\footnotetext{
${ }^{14}$ These figures are based on our main sample, which includes respondents ten to twenty years after graduation. Therefore, the lines for the basic track ends at an earlier age compared to the other tracks. Figure A.1 in the Appendix displays the patterns of family formation separately for males and females. It is evident that women are more likely than males to marry and to have a first child at younger ages. We examine effect differences between males and females in Section 7

${ }^{15}$ The differences are also in line with a pure selection effect in the sense that individuals with preferences for earlier marriage and earlier parenthood select themselves into lower tracks.
} 
where $Y_{i s c}$ is the outcome for individual $i$ in state $s$ and school starting cohort $c . S S Y_{s c}$ denotes the variable of interest. Based on an individuals' school starting cohort and state, it takes on the value 1 if an individual is exposed to two SSY and the value 0 if an individual is not exposed to SSY (see Section 3.2 for a detailed description of the exposure of different cohorts in the different states to short school years). Hence, $\beta$ denotes the effect of being exposed to two SSY, which is equivalent to graduating about two-thirds of a school year earlier. $\gamma_{s}$ and $\lambda_{c}$ are fixed effects for state and school starting cohorts, respectively, thus taking into account general differences in the outcomes between states and across school starting cohorts. $X_{i s c}$ is a vector of pre-determined individual characteristics. In the baseline specification, it includes a gender dummy and fixed effects for the wave of the Micro Census and, in our main specification, it includes interactions between the gender dummy and the fixed effects for cohort, state, and wave. Finally, $\varepsilon_{i s c}^{J}$ denotes the error term that is allowed to be clustered at the cohort-state level, i.e. the level the treatment variable is assigned.

We estimate Equation (2) separately by track for several reasons. First, the pattern of family formation differs between individuals across the three tracks in the sense that individuals in the basic track get married earlier and also give birth to children earlier (see Figure 2). Second, other reforms (in particular, the compulsory schooling reforms) implemented in a similar time period affected only specific tracks. Estimating the regressions separately for each track, allows for considering these other reforms more easily (see Section

6). Third, different cohorts are affected by SSY in the different tracks due to the differences in the number of years needed for graduation.

Our DiD identification strategy assumes that the track-specific family-formation outcomes would have evolved in parallel in the treated and control states, if SSY were not introduced. This common trend assumption could be violated if SSY exposure provoked parents to move to control states. Since the decisions on the SSY introduction were made at the beginning of 1966 and were communicated shortly before its implementation, it is unlikely that parents would have had enough time to move to avoid SSY exposure for their children. Further, moving across states is rather costly for families.

\section{Results}

We begin our discussion of the results by looking at the effect of the short school years on the probability to be married several years after graduation. We focus on the estimates for $\beta$ from Equation (2), the SSY effects. Column (1) of Table 2 suggests that being exposed to two short school years (i.e. graduating about two-thirds of a school year earlier) increases the probability to be married five years after graduation for individuals in the basic track by 0.4 
percentage points (pp). This effect is just beyond borderline significance at the $10 \%$ level and does not change substantially with the inclusion of gender-specific fixed effects for cohort, state, and wave (column 2). The marriage effect for individuals in the basic track remains statistically insignificant eight and ten years after graduation (columns 3-6). However, for individuals in the middle and academic tracks, the probability to be married five years after graduation increases substantially and significantly. While we see that the effects wash out over time, they are still statistically significant eight and ten years after graduation. The effect for the academic track decreases from $4.6 \mathrm{pp}$ (five years after) to $4.1 \mathrm{pp}$ (eight years after) and to $2.5 \mathrm{pp}$ (ten years after), while in the middle track it remains $3.7 \mathrm{pp}$ five years and eight years after, then decreases to $2.6 \mathrm{pp}$.

Next, we focus on SSY effects on the probability to have a first child five, eight, and ten years after graduation (Panel B). For individuals in the basic track, the earlier graduation due to SSY does not appear to result in increased probabilities to have a first child five, eight, or ten years after graduation. This is similar for individuals in the middle track, although the effect ten years after graduation is borderline significant. For individuals in the academic track affected by SSY, the probability to have a first child increases by about 3 pp eight and ten years after graduation.

While Table 2 focuses on three specific years after graduation, Figure 3 graphically shows the effects separately for one to ten years after graduation. In all three tracks, we observe a hump-shaped pattern for the marriage outcome: SSY exposure increases the probability to be married for the first years after graduation, but the effect fades over time. There is also evidence that SSY exposure significantly affects individuals in the basic track but only up to four years after graduation. For the fertility outcome, the point estimates are generally positive for the basic and middle tracks but statistically insignificant. However, for individuals in the academic track, SSY exposure does not only affect the timing of marriage, but also the timing of fertility: In Panel (f) of Figure 3 the point estimate is statistically significant for four to ten years after graduation. 16

Taken together, Table 2 and Figure 3 provide evidence that earlier graduation affects the timing of marriage for individuals across tracks, but that it shifts forward the birth of the

\footnotetext{
${ }^{16}$ Similar to Humlum et al. (2017), our main specification focuses on years after graduation and not on specific ages. When estimating the effects by age instead of years after graduation (see Table A.2 in the Appendix), we obtain similar results. The marriage effect first kicks in for individuals in the basic track with significant coefficients at ages 16-19, while for the middle track the largest point estimates are obtained at ages 20-25 and for the academic track at ages 23-27. The higher the education, the later the strongest effects. At age 29, the marriage effects remain significant only for the academic track. Panel B of this table shows significant fertility effects in the academic track for ages 21-29.
} 
first child mainly for individuals in the academic track. In the following, we discuss some explanations for these patterns. Once an individual enters the labor market, the German tax system induces strong incentives for getting married. For example, Germany's combination of progressive taxes and joint taxation (Ehegattensplitting) provides large financial benefits for married couples - in particular, for spouses with strongly differing income - and the social health insurance in Germany allows for insuring (non-working) spouses without cost. These incentives affect individuals in all three school tracks and, therefore, might explain why we find that individuals prepone marriage across tracks. Regarding the differential fertility response, Figure 2 provides evidence that the age at first birth is much higher for individuals in the academic track compared to individuals in the other tracks. Therefore, the fertility response to an earlier labor market entry might be stronger for individuals in this group, e.g., because they are closer to the biological age limit for childbirth or because they prefer that the age does not differ too much between parents and children.

\section{Sensitivity analysis}

Table 3 examines the sensitivity of our findings to alternative age, wave, and state restrictions.17 In our main specification, we construct the outcome variables based on information provided ten to twenty years after graduation. We set the lower bound to ten years in order to have a constant sample for five, eight, and ten years after graduation. Further, we do not include information from more than twenty years after graduation, as the more years after graduation we include, the more likely it is that marriages have been dissolved and/or children have moved out of the household. At the same time, a larger number of observations would increase the precision of our estimates. Hence, there is a bias-variance trade-off.

In the following, we analyze whether our results are robust to alternative ways of dealing with this bias-variance trade-off. Column (2) considers information by individuals ten to fifteen years after graduation, while column (3) considers information eight to twenty years after graduation. Column (4) includes only information by individuals eight to fifteen years after graduation, and column (5) relies on information provided between age 30 and 40 . The next two sensitivity analysis restrict the sample to fewer waves. Column (6) drops the last two waves (2002 and 2003) and column (7) disregards the first two waves (1976 and 1978). Columns (8) and (9) relate to the number of included states. Column (8) drops Lower Saxony

\footnotetext{
${ }^{17}$ This table presents the results for marriage and first birth eight years after graduation, tables A.3 and A.4 in Appendix A show the results for five and ten years after graduation, respectively.
} 
from the analysis, where SSY exposure was track-specific (see Section 2), while column (9) additionally includes Saarland, which was excluded in the main analyses due to earlier shifts of the start of the school year that affected many school starting cohorts in this particular state. Column (10) uses individuals' birth years (1945-1963) to identify treatment status by assuming a start of primary school in the year individuals turn seven, similar to the approach of Pischke (2007), but leaving all other sample restrictions unchanged. Column (11) clusters the standard errors at the level of the federal state and not at the state-cohort level. Our conclusions are insensitive to all the alternative specifications in Table 3.

In Appendix Table A.5, we deal with alternative cohort restrictions. First, we also include cohorts that were affected by SSY exposure in primary school. Second, we exclusively consider cohorts with two SSY and disregard cohorts with only one SSY. Third, we exclude the last pre-treatment cohort as the treatment status in this cohort would be wrongly assigned for individuals who repeated a grade. Again, our results are robust to these alternative specifications.

Co-treatments in the form of other policies are one threat to our identification strategy. For this reason, we excluded the school starting cohorts 1950 and 1951 (birth cohorts 1943 and 1944) from our main analysis. While these cohorts were included in previous SSY studies (Pischke, 2007, Braakmann, 2010), they were affected by reductions in the length of specific school years in four federal states (Baden-Württemberg, Bremen, Saarland, and West Berlin) due to moving the start of the school year from fall to Easter in line with the Düsseldorf Accord (DA) in 1955 (see also Footnote 2 and Figure B.1). We aim to only identify variations in the length of the schooling phase induced by the 1966/67 short school years, for which previous studies show that they did not hamper human capital accumulation. That is why we excluded Saarland completely from the main analysis: in this state, later cohorts were also affected by other changes in the length of the schooling phase.

Further, during our observation period, several states increased compulsory schooling from eight to nine years. This change mainly affected the basic track, as the regular school length is ten years in the middle track and thirteen years in the academic track. However, previous studies use two slightly different sets of compulsory schooling reform dates (we discuss this in more detail in Appendix B . Therefore, we searched for the original law texts and propose refined reform dates, which we display together with the primary sources in Tables B.1.B.11 and Table B.12 in Appendix B. We use these reform dates to assign to each cohort in each state the compulsory number of school years. Table A.6 shows the results for the basic track when we control for compulsory schooling reforms using our refined dates or reform dates 
used in Pischke (2007). Controlling for compulsory schooling does not change our results meaningfully - irrespective of the used set of reform dates.

\section{Further results}

This section presents different sets of additional results on (i) effect differences by gender; (ii) longer time horizons; (iii) the exact timing of marriage and parenthood; and (iv) subsequent births.

\subsection{Gender-specific results}

Thus far, we pool the effects for males and females. Table 4 splits the sample according to an individual's gender. It shows that the obtained marriage and fertility effects are driven by both males and females. Generally, the effects for five years after graduation are slightly larger for females than for males. One reason for this might be that females are, on average, younger than males when they marry and have children (see also Figure A.1). For instance, about $30 \%$ of middle track women in our sample are married five years after graduation, while the corresponding share is only $12 \%$ for men. The effect differences between women and men become smaller eight and ten years after graduation, i.e. when men are also more likely to be married and have a first child.

\subsection{Long-run effects}

To analyze whether SSY affect only the timing of family formation or also the probability to ever marry/have children, this subsection focuses on longer time horizons. More specifically, Table 5 looks at family formation 10 to 15 years after graduation 18 The table shows a striking pattern: The longer the considered time horizon, the smaller the previously significant effects. For instance, while individuals in the middle track are 2.6 percentage points more likely to marry in the first ten years after graduation due to SSY exposure, this effect decreases to 1.8 percentage points twelve years after graduation and to 0.1 percentage points fifteen years after graduation. Similar patterns can be observed in the other panels that previously exhibited significant effects. All-in-all, Table 5 suggests that the SSY introduction affected the timing of marriage and parenthood, but not the probability to ever marry or become a parent. Therefore, the short school years are rather a "tempo policy" (Lutz and Skirbekk, 2005) as they basically affect the timing of family formation.

\footnotetext{
${ }^{18}$ While our main analyses focuses on the reports of individuals 10 to 20 years after graduation, these analyses consider reports of individuals $p$ to 20 years after graduation, where $p \in[10,15]$ is the number of years until which the event could have taken place in the respective analysis. Therefore, the number of observations differs across the specifications in Table 5.
} 


\subsection{Exact timing of marriage and parenthood}

While the previous analyses focus on the probability of family formation at or before a specific point in time, the next analysis looks at the probability of family formation at a

specific point in time 19 This analysis helps to better understand the effects of SSY exposure on the exact timing of marriage and parenthood. Figure 3 graphically presents the associated results. Generally, the largest positive point estimates for marriage are found in periods when marriage is most likely (compare Figure 2c). Interestingly, significant and positive point estimates for marriage precede negative coefficients in all three tracks. For instance, individuals in the academic track are significantly more likely to marry in the second, third, fourth, and fifth years after graduation due to SSY exposure, while they are significantly less likely to marry in the eighth and ninth years after graduation. This shows that the control cohorts are catching-up over time and that the head start of the treated cohorts declines over time, suggesting similar effects to the findings in the previous subsection that SSY exposure affects the timing of marriage, but not the overall probability to ever marry. Moreover, this pattern also shows why point estimates in our main specification (with cumulative marriage rates) are higher five years after graduation than ten years after graduation. For parenthood, all coefficients for $t \in[2,9]$ years after graduation are clearly positive and some coefficients are significant at the $10 \%$ level. Moreover, the magnitude of the coefficients declines for $t \in[8,10]$ years after graduation, suggesting a similar pattern as for the marriage outcomes.

\subsection{Subsequent births}

The following analysis examines whether short school years also affected the timing of the birth of the second child. For this analysis, we use the same sample as in the main specification but redefine the outcome variable from Equation (1) in such a way that it only takes on the value of 1 if two children were born at or before a specific point in time (instead of just one child). Table 6 provides evidence that SSY exposure increased the probability for individuals in the academic track to have two children eight to ten years after graduation by about 1.5 percentage points. As expected, the point estimates are smaller than the effects for the first child (compare Figure 3) and they turn significant only for later years. There is also some evidence for positive effects in the middle track, but the effects are smaller and only borderline significant. We refrain from examining higher order parities or completed

\footnotetext{
${ }^{19}$ For this analysis, we redefine our outcome variables from Equation (1) as

$$
Y^{e, p}= \begin{cases}1 & \text { if event } e \text { in } t=p \\ 0 & \text { otherwise }\end{cases}
$$
}


fertility as we only observe children who are still living in the household of their parents (see also the discussion in Section 3). For these outcomes, measurement error would not only be much larger but also potentially systematic.

\section{Discussion and conclusion}

This study examines the effects on the timing of fertility and marriage of a policy that allowed students to finish secondary school about eight months earlier - with the same degree and the same curriculum taught. We find that earlier graduation leads to earlier marriages. There is also evidence that the earlier graduation affects the timing of childbirth. We find that the effects fade over time, indicating that the short school years affected the timing of marriage and parenthood but not the probability to ever marry or to become a parent. We further show that the obtained effects are driven by both males and females and that the reform affected also the probability to have a second child within the first ten years after graduation.

Our findings highlight that policies altering the duration of specific life phases can affect the timing of marriage and childbirth. This is relevant for both academic and political discussions. Our study contributes to the literature on policies that affect family formation by highlighting the importance of unintended consequences of policies that reduce or extend specific life phases. Our study also contributes to the literature on the relationship between education and family formation by proposing the "duration effect" as a third mechanism, how education might causally affect family formation. While the previous literature focuses on human capital effects and lock-in effects, the duration effect is so far neglected. We provide evidence that education influences family formation through its effect on the timing of subsequent life phases that individuals typically traverse before forming families. Another contribution of this study is the compilation of relevant education reforms in West Germany and the respective law sources, which can be also used by other researchers.

Our findings carry also important messages for policymakers. On the one hand, policymakers should be aware of the consequences for family formation when discussing policies that affect the duration of specific life phases (e.g., changing the duration of compulsory military service, secondary schooling, or university education). On the other hand, our study highlights that these policies might offer a tool for policymakers who would like to change the timing of family formation. Both aspects are particularly relevant, given that not only is the age at marriage and age of first birth increasing in many countries, but the duration of the education phase is also increasing. 


\section{References}

Alm, J. and L. A. Whittington (1997). Income taxes and the timing of marital decisions. Journal of Public Economics 64(2), 219-240.

Backhaus, H. (1963). Das neunte Schuljahr: Eine Darstellung des Bestandes, der Versuche und der Diskussion. Heidelberg: Quelle \& Meyer.

Baker, M., J. Kantarevic, and E. Hanna (2004). The married widow: Marriage penalties matter! Journal of the European Economic Association 2(4), 634-664.

Bauer, T. K., S. Bender, A. R. Paloyo, and C. M. Schmidt (2012). Evaluating the labormarket effects of compulsory military service. European Economic Review 56(4), 814-829.

Bauernschuster, S., T. Hener, and H. Rainer (2016). Children of a (Policy) Revolution: the Introduction of Universal Child Care and Its Effect on Fertility. Journal of the European Economic Association 14(4), 975-1005.

Becker, G. S. (1981). A Treatise on the Family. Cambridge, MA: Harvard University Press.

Billari, F. C., A. C. Liefbroer, and D. Philipov (2006). The Postponement of Childbearing in Europe: Driving Forces and Implications. Vienna Yearbook of Population Research 4, $1-17$.

Billari, F. C., P. Manfredi, and A. Valentini (2000). Macro-demographic effects of the transition to adulthood: Multistate stable population theory and an application to Italy. Mathematical Population Studies 9(1), 33-63.

Björklund, A. (2006). Does family policy affect fertility?: Lessons from Sweden. Journal of Population Economics 19(1), 3-24.

Black, S. E., P. J. Devereux, and K. G. Salvanes (2008). Staying in the classroom and out of the maternity ward? The effect of compulsory schooling laws on teenage births. Economic Journal 118(530), 1025-1054.

Black, S. E., P. J. Devereux, and K. G. Salvanes (2011). Too young to leave the nest? The effects of school starting age. The Review of Economic Studies 93(May), 455-467.

Blossfeld, H.-P. and A. D. Rose (1992). Educational Expansion and Changes in Entry into Marriage and Motherhood. The Experience of Italien Women. Genus 48(3/4), 73-91.

Bömmel, N. and G. Heineck (2020). Revisiting the Causal Effect of Education on Political Participation and Interest. IZA Discussion Paper Series 13954.

Braakmann, N. (2010). A note on the causal link between education and health - Evidence from the German short school years. University of Lüneburg Working Paper Series in Economics 176 . 
Cherlin, A. J. (2003). Should the government promote marriage? Contexts 2(4), 22-29.

Currie, J. and E. Moretti (2003). Mother's education and the intergenerational transmission of human capital: Evidence from college openings. Quarterly Journal of Economics 118(4), $1495-1532$.

Cygan-Rehm, K. (2016). Parental leave benefit and differential fertility responses: evidence from a German reform. Journal of Population Economics 29(1), 73-103.

Cygan-Rehm, K. (2018). Is additional schooling worthless? Revising the zero returns to compulsory schooling in Germany. CESIFO Working Papers Series 7191.

Cygan-Rehm, K. and M. Maeder (2013). The effect of education on fertility: Evidence from a compulsory schooling reform. Labour Economics 25, 35-48.

Devereux, P. J. and G. Tripathi (2009). Optimally combining censored and uncensored datasets. Journal of Econometrics 151(1), 17-32.

Díaz-Giménez, J. and E. Giolito (2013). Accounting for the timing of first marriage. International Economic Review 54(1), 135-158.

Dustmann, C., P. A. Puhani, and U. Schönberg (2017). The Long-term Effects of Early Track Choice. Economic Journal 127(603), 1348-1380.

Fink, A. (2020). German income taxation and the timing of marriage. Applied Economics 52(5), 475-489.

Fort, M., N. Schneeweis, and R. Winter-Ebmer (2016). Is Education Always Reducing Fertility? Evidence from Compulsory Schooling Reforms. Economic Journal 126(595), $1823-1855$.

Fort, M., N. E. Schneeweis, and R. Winter-Ebmer (2011). More Schooling, More Children: Compulsory Schooling Reforms and Fertility in Europe. IZA Discussion Paper Series 6015.

Frimmel, W., M. Halla, and R. Winter-Ebmer (2014). Can Pro-Marriage Policies Work? An Analysis of Marginal Marriages. Demography 51(4), 1357-1379.

Froese, L. (1969). Bildungspolitik und Bildungsreform: Amtliche Texte und Dokumente zur Bildungspolitik im Deutschland der Besatzungszonen, der Bundesrepublik Deutschland und der Deutschen Demokratischen Republik (Goldmanns ed.). München: Goldmann.

Gauthier, A. H. (2007). The impact of family policies on fertility in industrialized countries: a review of the literature. Population Research and Policy Review 26(3), 323-346.

German Federal Statistical Office (1973). I. Allgemeinbildende Schulen. Fachserie A: Bevölkerung und Kultur. Reihe 10 Bildungswesen. Various Years (1961-1973).

Grönqvist, H. and C. Hall (2013). Education policy and early fertility: Lessons from an expansion of upper secondary schooling. Economics of Education Review 37, 13-33. 
Gustafsson, S. (2001). Optimal age at motherhood. Theoretical and empirical considerations on postponement of maternity in Europe. Journal of Population Economics 14(2), 225247.

Hahm, S. and J. Kluve (2019). Better with Bologna? Tertiary education reform and student outcomes. Education Economics 27(4), 425-449.

Halla, M., M. Lackner, and J. Scharler (2016). Does the Welfare State Destroy the Family? Evidence from OECD Member Countries. Scandinavian Journal of Economics 118(2), 292-323.

Hampf, F. (2019). The Effect of Compulsory Schooling on Skills: Evidence from a Reform in Germany. ifo Working Paper Series 313.

Helbig, M. and R. Nikolai (2015). Die Unvergleichbaren. Der Wandel der Schulsysteme in den deutschen Bundesländern seit 1949. Bad Heilbrunn: Klinkhardt.

Hodsdon, P. J. and M. M. Marini (2019). Effects of the Timing of Marriage and First Birth of the Spacing of Subsequent Births. Demography 18(4), 529-548.

Huebener, M. (2019). Life expectancy and parental education. Social Science and Medicine 232, 351-365.

Huebener, M. and J. Marcus (2017). Compressing instruction time into fewer years of schooling and the impact on student performance. Economics of Education Review 58, $1-14$.

Huinink, J. and M. Kohli (2014). A life-course approach to fertility. Demographic Research 30(1), 1293-1326.

Humlum, M. K., J. H. Kristoffersen, and R. Vejlin (2017). College admissions decisions, educational outcomes, and family formation. Labour Economics 48, 215-230.

Imbens, G. and W. van der Klaauw (1995). Evaluating the cost of conscription in the Netherlands. Journal of Business and Economic Statistics 13(2), 207-215.

Jejeebhoy, S. J. (1995). Women's Education, Autonomy, and Reproductive Behaviour: Experience from Developing Countries. OUP Catalogue. Oxford University Press.

Jürges, H., S. Reinhold, and M. Salm (2011). Does schooling affect health behavior? Evidence from the educational expansion in Western Germany. Economics of Education Review 30(5), 862-872.

Kamhöfer, D. A. and M. Westphal (2019). Fertility Effects of College Education: Evidence from the German Educational Expansion. DICE Discussion Paper Series 316.

Kemptner, D., H. Jürges, and S. Reinhold (2011). Changes in compulsory schooling and the causal effect of education on health: Evidence from Germany. Journal of Health Economics 30(2), 340-354. 
Kluve, J. and S. Schmitz (2018). Back to Work: Parental Benefits and Mothers' Labor Market Outcomes in the Medium Run. ILR Review 71(1), 143-173.

KMK (1962). Schuljahresbeginn - Frühjahr oder Herbst? Dokumentation. Technical report, Standing Conference of the Ministers of Education and Cultural affairs of the Länder in the Federal Republic of Germany.

Krapf, S. and M. Kreyenfeld (2015). Fertility assessment with the own-children method: A validation with data from the German Mikrozensus. Technical report, Max Planck Institute for Demographic Research, Rostock.

Lalive, R. and J. Zweimüller (2009). How does Parental Leave affect Fertility and Return to Work? Evidence from two Natural Experiments. The Quarterly Journal of Economics 124(8210), 3.

Larsen, U. and J. W. Vaupel (1993). Hutterite fecundability by age and parity: strategies for frailty modeling of event histories. Demography 30(1), 81-102.

Leschinsky, A. and P. M. Roeder (1980). Didaktik und Unterricht in der Sekundarstufe I seit 1950. Entwicklung der Rahmenbedingungen. In Max-Planck-Institut für Bildungsforschung: Projektgruppe Bildungsbericht (Ed.), Bildung in der Bundesrepublik Deutschland. Daten und Analysen. Bd.1: Entwicklungen seit 1950, Chapter VI A, pp. 283-391. Hamburg and Stuttgart.

Lutz, W. and V. Skirbekk (2005). Policies Addressing the Tempo Effect in Low-Fertility Countries. Population and Development Review 31 (4), 699-720.

Marcus, J. and V. Zambre (2019). The effect of increasing education efficiency on university enrollment: Evidence from administrative data and an unusual schooling reform in Germany. Journal of Human Resources 54 (2), 468-502.

Margaryan, S., A. Paul, and T. Siedler (2020). Does Education Affect Attitudes towards Immigration? Evidence from Germany. Journal of Human Resources (forthcoming).

McCrary, J. and H. Royer (2011). the Effect of Female Education on Fertility and Infant Health: Evidence From School Entry Policies Using Exact Date of Birth. American Economic Review 101(1), 158-195.

Monstad, K., C. Propper, and K. G. Salvanes (2008). Education and fertility: Evidence from a natural experiment. Scandinavian Journal of Economics 110(4), 827-852.

Mörk, E., A. Sjögren, and H. Svaleryd (2013). Childcare costs and the demand for children - evidence from a nationwide reform. Journal of Population Economics 26(1), 33-65.

Myrskylä, M. and A. Fenelon (2012). Maternal Age and Offspring Adult Health: Evidence From the Health and Retirement Study. Demography 49(4), 1231-1257. 
OECD (2019). Family Database SF2.3: Age of mothers at childbirth and age-specific fertility. Technical report, OECD-Social Policy Division.

Oppenheimer, V. K. (1997). Women's Employment and the Gain to Marriage: The Specialization and Trading Model. Annual Review of Sociology 23(1), 431-453.

Persson, P. (2020). Social insurance and the marriage market. Journal of Political Economy 128(1), 252-300.

Petzold, H.-J. (1981). Schulzeitverlängerung: Parkplatz oder Bildungschance? Die Funktion des 9. und 10. Schuljahres. Bensheim: Päd.-Extra-Buchverlag.

Piopiunik, M. (2011). Intergenerational Transmission of Education and Mediating Channels: Evidence from Compulsory Schooling Reforms in Germany. ifo Working Paper Series $10 \%$.

Piopiunik, M. (2014). Intergenerational Transmission of Education and Mediating Channels: Evidence from a Compulsory Schooling Reform in Germany. Scandinavian Journal of Economics 116(3), 878-907.

Pischke, J.-S. (2007). The impact of length of the school year on student performance and earnings: Evidence from the German short school years. Economic Journal 117(10), 12161242.

Pischke, J.-S. and T. von Wachter (2005). Zero returns to compulsory schooling in Germany: Evidence and interpretation. NBER Working Paper Series 11414.

Pischke, J.-S. and T. von Wachter (2008). Zero returns to compulsory schooling in Germany: Evidence and interpretation. Review of Economics and Statistics 90(3), 592-598.

Raute, A. (2019). Can financial incentives reduce the baby gap? Evidence from a reform in maternity leave benefits. Journal of Public Economics 169, 203-222.

RDC (2019). Microcensus Waves 1976-2003. Scientific Use Files. Technical report, Research Data Centres of the Federal Statistical Office and the Statistical Offices of the Länder.

Rindfuss, R. R., D. K. Guilkey, S. P. Morgan, and Ø. Kravdal (2010). Child-care availability and fertility in Norway. Population and Development Review 36(4), 725-748.

Siedler, T. (2010). Schooling and citizenship in a young democracy: Evidence from postwar Germany. Scandinavian Journal of Economics 112(2), 315-338.

Silles, M. A. (2011). The effect of schooling on teenage childbearing: evidence using changes in compulsory education laws. Journal of Population Economics 24(2), 761-777.

Skirbekk, V. (2008). Fertility trends by social status. Demographic research 18(5), 145-180.

Tan, P. L. (2017). The impact of school entry laws on female education and teenage fertility. Journal of Population Economics 30(2), 503-536. 


\section{Tables and Figures}

Figure 1: Exposure to Short School Years by Secondary School Track and Cohort

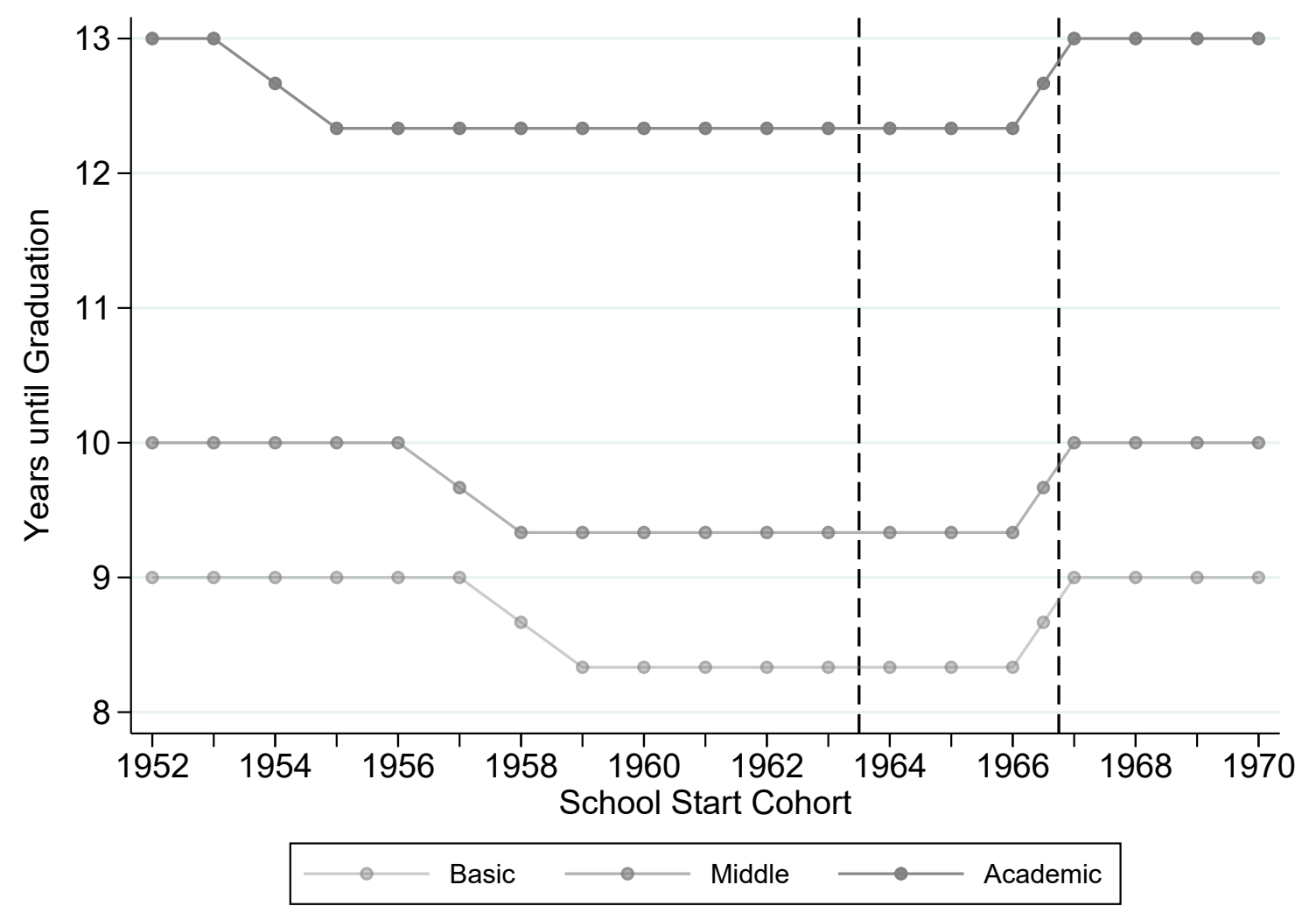

Notes: This stylized figure visualizes treatment identification in a given treatment state, depending on school start cohort and secondary school track. School starting cohorts within the dashed lines are cohorts that were affected by the short school years during primary school and that are excluded in our main analyses. Deviations from the regular school years required in each track (9 in basic, 10 in middle, and 13 in academic) imply exposure to short school years. Own calculations and graphical display. 

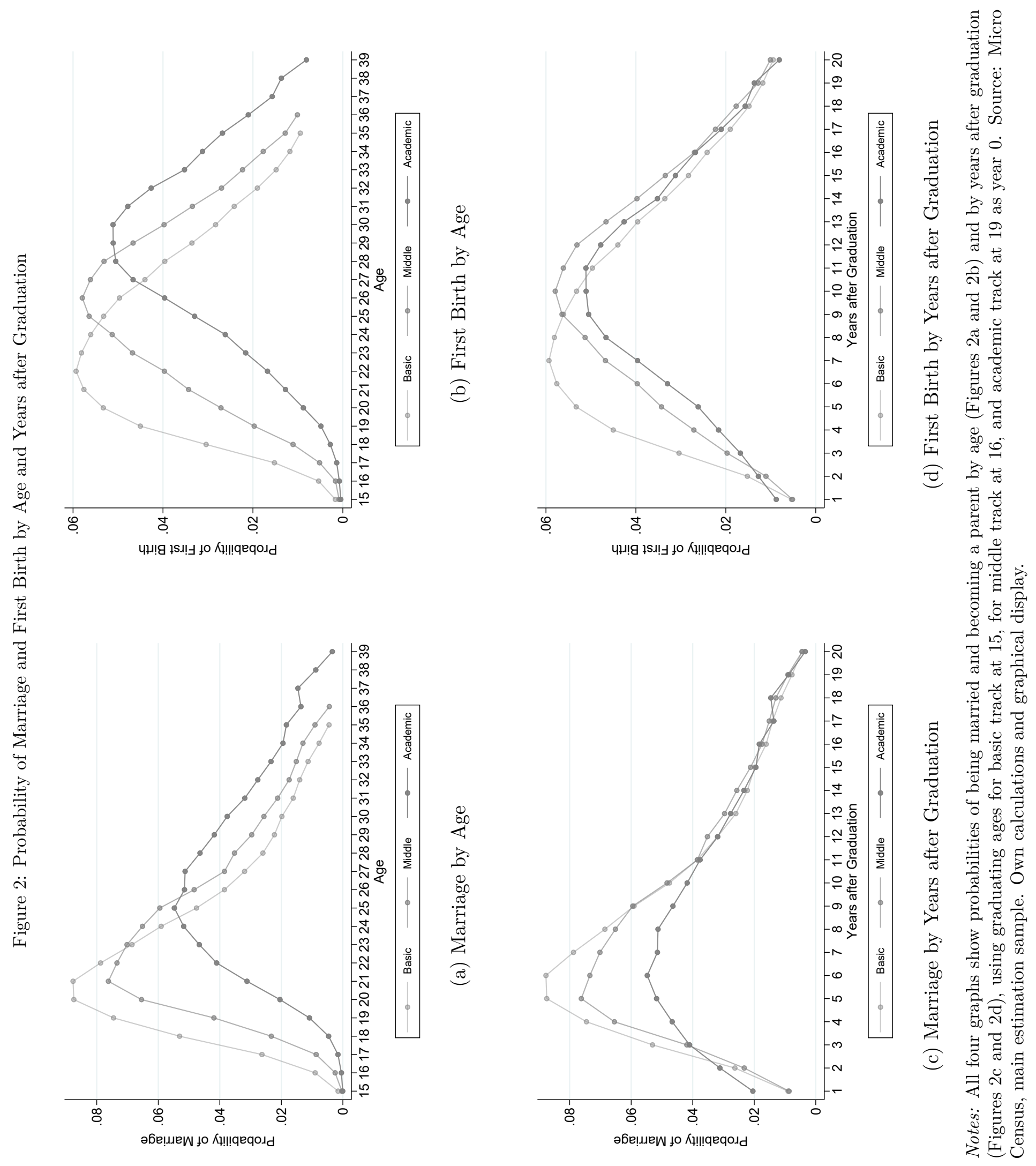
Figure 3: Effect of Short School Years on Marriage and First Birth

(a) Marriage - Basic

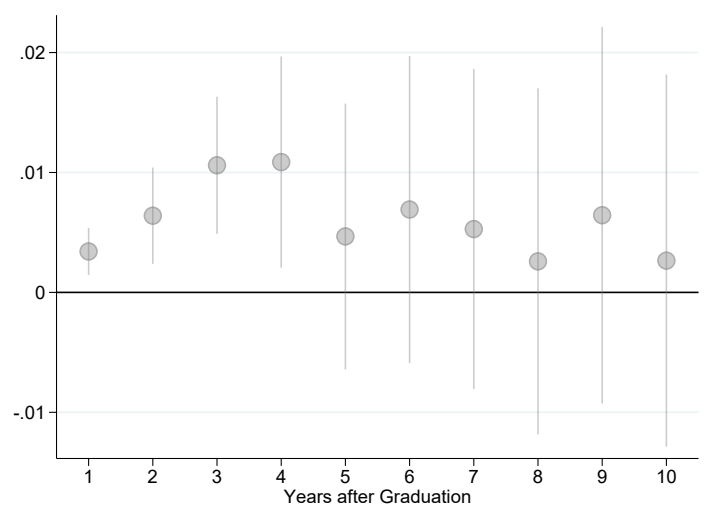

(c) Marriage - Middle

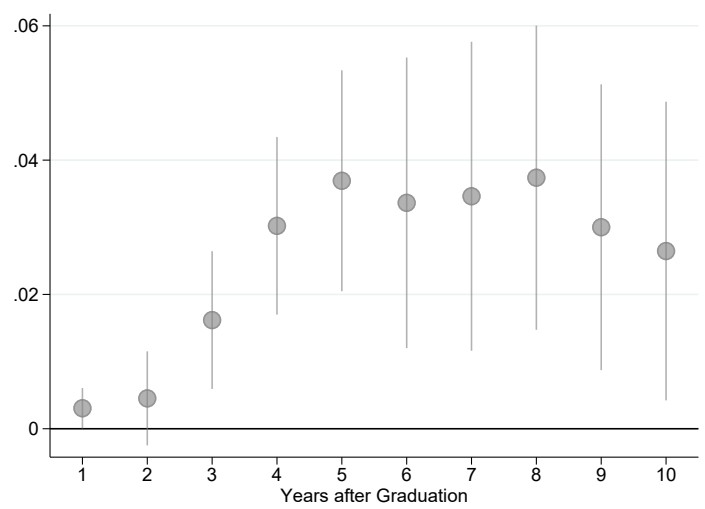

(e) Marriage - Academic

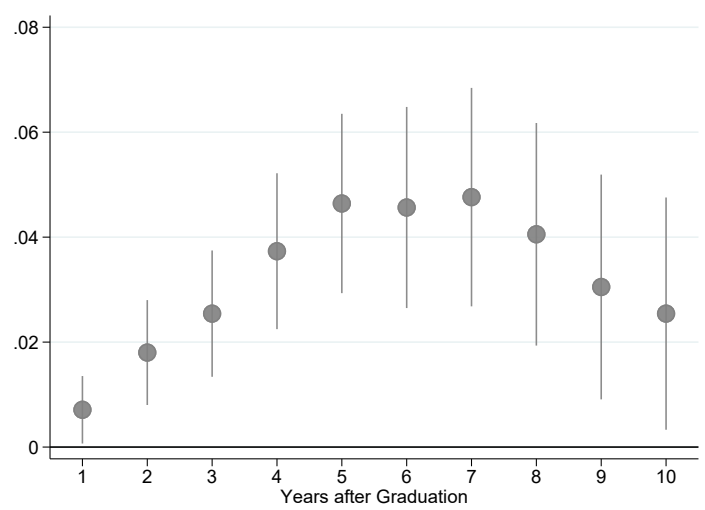

(b) First Birth - Basic

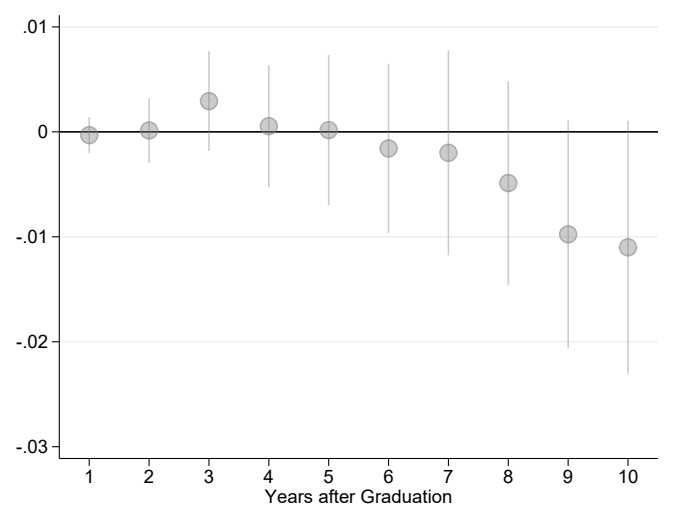

(d) First Birth - Middle

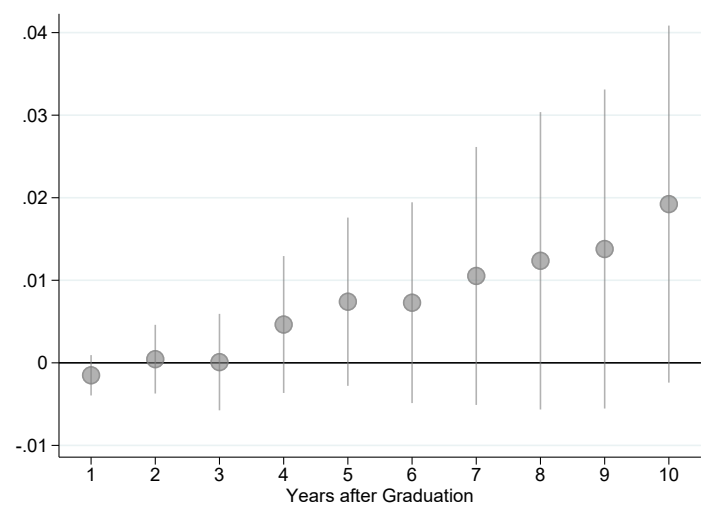

(f) First Birth - Academic

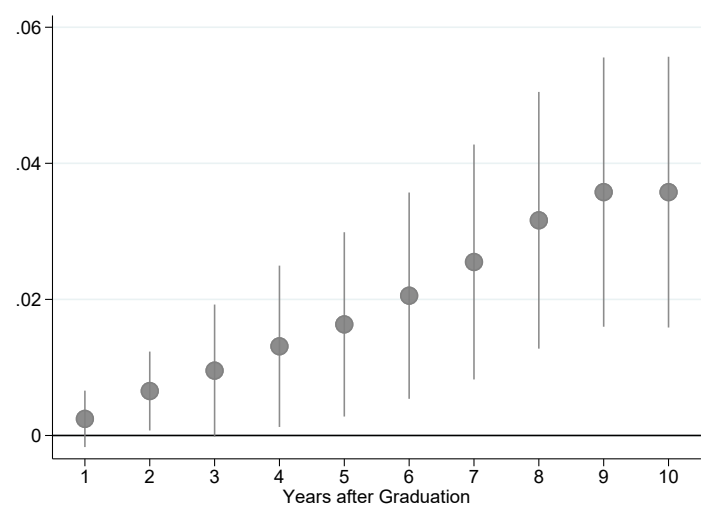

Notes: The graphs show the estimated short school year effects (and their $95 \%$ confidence intervals) up to different years after graduation. The underlying samples are identical to the samples in Table 2, All coefficients are based on Equation (2). 
Figure 4: Effect of Short School Years at different Years after Graduation

(a) Marriage - Basic

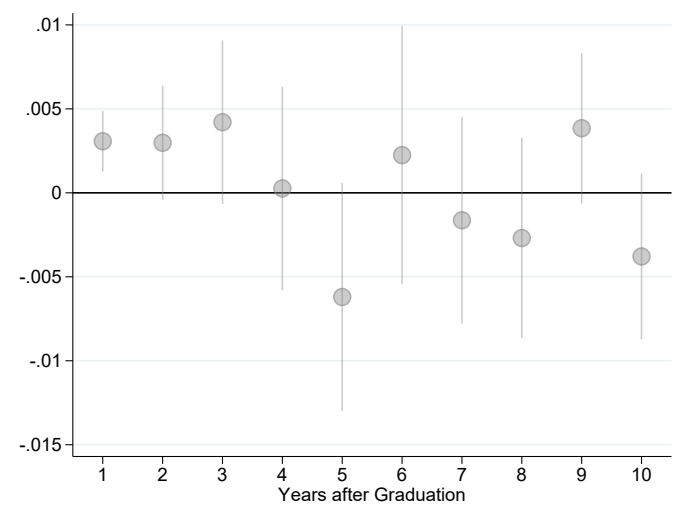

(c) Marriage - Middle

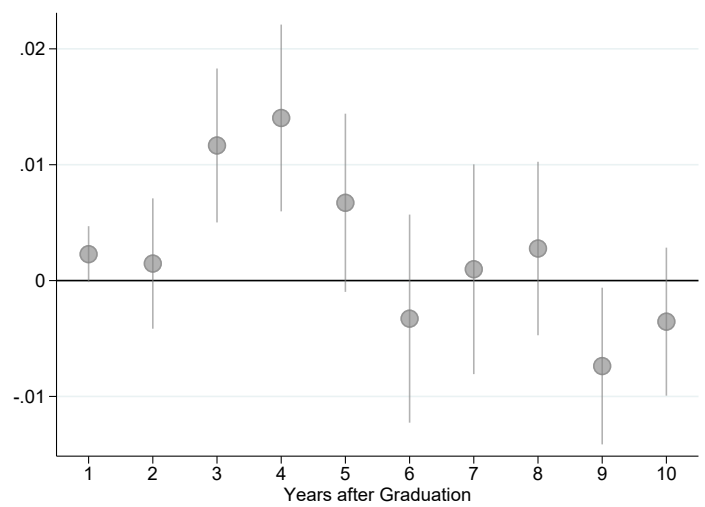

(e) Marriage - Academic

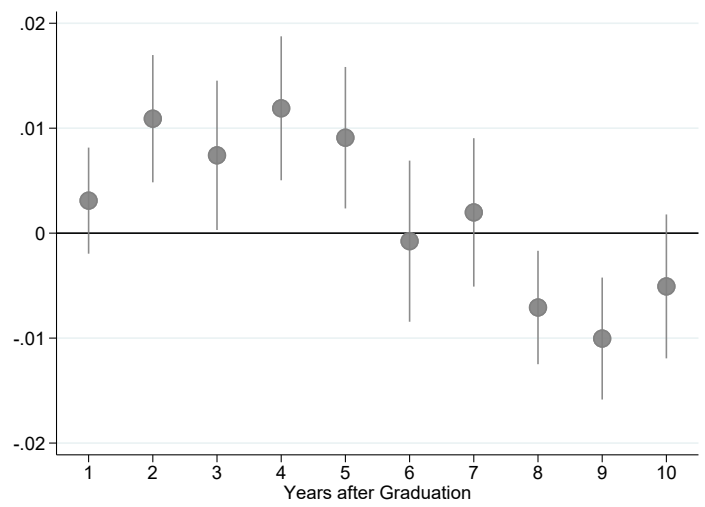

(b) First Birth - Basic

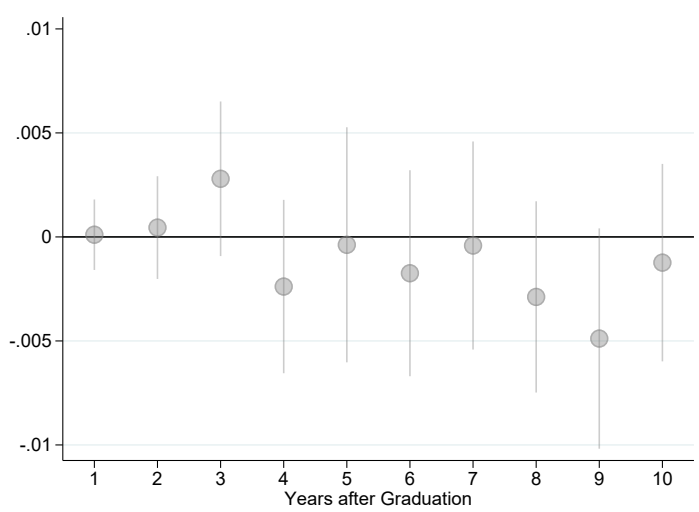

(d) First Birth - Middle

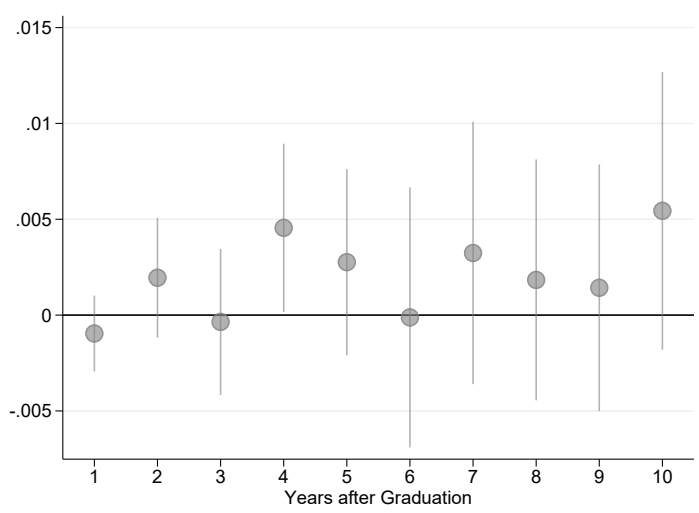

(f) First Birth - Academic

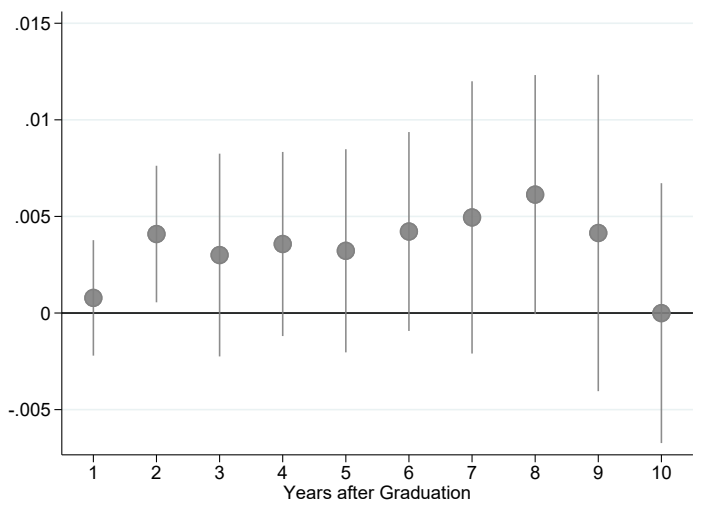

Notes: The graphs show the estimated short school year effects (and their $95 \%$ confidence intervals) at different years after graduation. The underlying samples are identical to the samples in Table 2 and all coefficients are based on Equation (2). The figure is related to Figure 3 , which shows short school year effects up to different years after graduation. 
Table 1: Summary Statistics by Secondary School Track

\begin{tabular}{|c|c|c|c|c|c|c|c|c|c|}
\hline & \multicolumn{3}{|c|}{ Basic } & \multicolumn{3}{|c|}{ Middle } & \multicolumn{3}{|c|}{ Academic } \\
\hline & Mean & Min & Max & Mean & Min & Max & Mean & Min & Max \\
\hline Female & 0.49 & 0 & 1 & 0.58 & 0 & 1 & 0.42 & 0 & 1 \\
\hline Birthyear & 1954.38 & 1945 & 1964 & 1956.54 & 1945 & 1964 & 1957.15 & 1945 & 1964 \\
\hline \multicolumn{10}{|l|}{ Birthmonth } \\
\hline Jan-Apr & 0.36 & 0 & 1 & 0.37 & 0 & 1 & 0.37 & 0 & 1 \\
\hline May-Dec & 0.64 & 0 & 1 & 0.63 & 0 & 1 & 0.63 & 0 & 1 \\
\hline Age at Interview & 30.75 & 25 & 35.5 & 31.93 & 26 & 36.5 & 34.89 & 29 & 39.5 \\
\hline School Start Year & 1961.04 & 1952 & 1970 & 1963.19 & 1952 & 1970 & 1963.80 & 1952 & 1970 \\
\hline Years in School & 8.52 & 8 & 9 & 9.85 & 9.33 & 10 & 12.79 & 12.3 & 13 \\
\hline \multicolumn{10}{|l|}{ Marital Status } \\
\hline Single & 0.22 & 0 & 1 & 0.25 & 0 & 1 & 0.32 & 0 & 1 \\
\hline Married & 0.73 & 0 & 1 & 0.70 & 0 & 1 & 0.64 & 0 & 1 \\
\hline Widowed & 0.00 & 0 & 1 & 0.00 & 0 & 1 & 0.00 & 0 & 1 \\
\hline Divorced & 0.05 & 0 & 1 & 0.05 & 0 & 1 & 0.04 & 0 & 1 \\
\hline Age at Marriage & 22.65 & 15.5 & 35.5 & 23.99 & 15.5 & 36.5 & 26.74 & 15.5 & 39.5 \\
\hline \multicolumn{10}{|l|}{ Share Married } \\
\hline 5 Years after Graduation & 0.25 & 0 & 1 & 0.22 & 0 & 1 & 0.21 & 0 & 1 \\
\hline 8 Years after Graduation & 0.49 & 0 & 1 & 0.43 & 0 & 1 & 0.37 & 0 & 1 \\
\hline 10 Years after Graduation & 0.59 & 0 & 1 & 0.53 & 0 & 1 & 0.45 & 0 & 1 \\
\hline Age at First Birth & 23.73 & 15 & 35.5 & 25.58 & 15 & 36.5 & 28.44 & 15 & 39.5 \\
\hline \multicolumn{10}{|l|}{ Share First Birth } \\
\hline 5 Years after Graduation & 0.15 & 0 & 1 & 0.10 & 0 & 1 & 0.10 & 0 & 1 \\
\hline 8 Years after Graduation & 0.33 & 0 & 1 & 0.24 & 0 & 1 & 0.22 & 0 & 1 \\
\hline 10 Years after Graduation & 0.44 & 0 & 1 & 0.35 & 0 & 1 & 0.32 & 0 & 1 \\
\hline Childless at Interview & 0.38 & 0 & 1 & 0.43 & 0 & 1 & 0.48 & 0 & 1 \\
\hline
\end{tabular}

Notes: The table displays for relevant variables sample mean, minimum and maximum by secondary school track. 
Table 2: Effect of Short School Years on Marriage and First Birth

\begin{tabular}{|c|c|c|c|c|c|c|}
\hline & \multicolumn{2}{|c|}{5 Years } & \multicolumn{2}{|c|}{8 Years } & \multicolumn{2}{|c|}{10 Years } \\
\hline & (1) & $(2)$ & (3) & (4) & (5) & (6) \\
\hline \multicolumn{7}{|l|}{ Panel A: Marriage } \\
\hline Basic & $\begin{array}{c}0.004 \\
(0.006)\end{array}$ & $\begin{array}{c}0.005 \\
(0.006)\end{array}$ & $\begin{array}{c}0.002 \\
(0.007)\end{array}$ & $\begin{array}{c}0.003 \\
(0.007)\end{array}$ & $\begin{array}{c}0.003 \\
(0.008)\end{array}$ & $\begin{array}{c}0.003 \\
(0.008)\end{array}$ \\
\hline $\mathrm{N}$ & 203,501 & 203,501 & 203,501 & 203,501 & 203,501 & 203,501 \\
\hline Middle & $\begin{array}{c}0.038^{* * *} \\
(0.008)\end{array}$ & $\begin{array}{c}0.037^{* * *} * \\
(0.008)\end{array}$ & $\begin{array}{c}0.038^{* * *} \\
(0.011)\end{array}$ & $\begin{array}{c}0.037^{* * *} \\
(0.011)\end{array}$ & $\begin{array}{c}0.026^{* *} \\
(0.011)\end{array}$ & $\begin{array}{c}0.026^{* *} \\
(0.011)\end{array}$ \\
\hline $\mathrm{N}$ & 98,448 & 98,448 & 98,448 & 98,448 & 98,448 & 98,448 \\
\hline Academic & $\begin{array}{c}0.046^{* * *} \\
(0.009)\end{array}$ & $\begin{array}{c}0.046^{* * *} \\
(0.009)\end{array}$ & $\begin{array}{c}0.041^{* * *} \\
(0.011)\end{array}$ & $\begin{array}{c}0.041^{* * *} \\
(0.011)\end{array}$ & $\begin{array}{c}0.025^{* *} \\
(0.011)\end{array}$ & $\begin{array}{c}0.025^{* *} \\
(0.011)\end{array}$ \\
\hline $\mathrm{N}$ & 109,199 & 109,199 & 109,199 & 109,199 & 109,199 & 109,199 \\
\hline Panel B: First Birth & & & & & & \\
\hline Basic & $\begin{array}{l}-0.000 \\
(0.004)\end{array}$ & $\begin{array}{c}0.000 \\
(0.004)\end{array}$ & $\begin{array}{l}-0.005 \\
(0.005)\end{array}$ & $\begin{array}{l}-0.005 \\
(0.005)\end{array}$ & $\begin{array}{c}-0.011^{*} \\
(0.006)\end{array}$ & $\begin{array}{c}-0.011^{*} \\
(0.006)\end{array}$ \\
\hline $\mathrm{N}$ & 203,501 & 203,501 & 203,501 & 203,501 & 203,501 & 203,501 \\
\hline Middle & $\begin{array}{c}0.008 \\
(0.005)\end{array}$ & $\begin{array}{c}0.007 \\
(0.005)\end{array}$ & $\begin{array}{c}0.013 \\
(0.009)\end{array}$ & $\begin{array}{c}0.012 \\
(0.009)\end{array}$ & $\begin{array}{c}0.019^{*} \\
(0.011)\end{array}$ & $\begin{array}{l}0.019^{*} \\
(0.011)\end{array}$ \\
\hline $\mathrm{N}$ & 98,448 & 98,448 & 98,448 & 98,448 & 98,448 & 98,448 \\
\hline Academic & $\begin{array}{c}0.016^{* *} \\
(0.007)\end{array}$ & $\begin{array}{c}0.016^{* *} \\
(0.007)\end{array}$ & $\begin{array}{c}0.032^{* * *} \\
(0.010)\end{array}$ & $\begin{array}{c}0.032^{* * *} \\
(0.010)\end{array}$ & $\begin{array}{c}0.036^{* * *} \\
(0.010)\end{array}$ & $\begin{array}{c}0.036^{* * *} \\
(0.010)\end{array}$ \\
\hline $\mathrm{N}$ & 109,199 & 109,199 & 109,199 & 109,199 & 109,199 & 109,199 \\
\hline School Cohort FE & Yes & Yes & Yes & Yes & Yes & Yes \\
\hline State FE & Yes & Yes & Yes & Yes & Yes & Yes \\
\hline Sex FE & Yes & Yes & Yes & Yes & Yes & Yes \\
\hline Wave FE & Yes & Yes & Yes & Yes & Yes & Yes \\
\hline School Cohort-Sex FE & No & Yes & No & Yes & No & Yes \\
\hline State-Sex FE & No & Yes & No & Yes & No & Yes \\
\hline Wave-Sex FE & No & Yes & No & Yes & No & Yes \\
\hline
\end{tabular}

Notes: The table shows the effect of the short school years on marriage and first birth five, eight, and ten years after graduation from secondary school for individuals in different secondary school tracks based on Equation (2). Standard errors clustered at the cohortstate level in parentheses. ${ }^{*} p<0.1,{ }^{* *} p<0.05,{ }^{* * *} p<0.01$. 


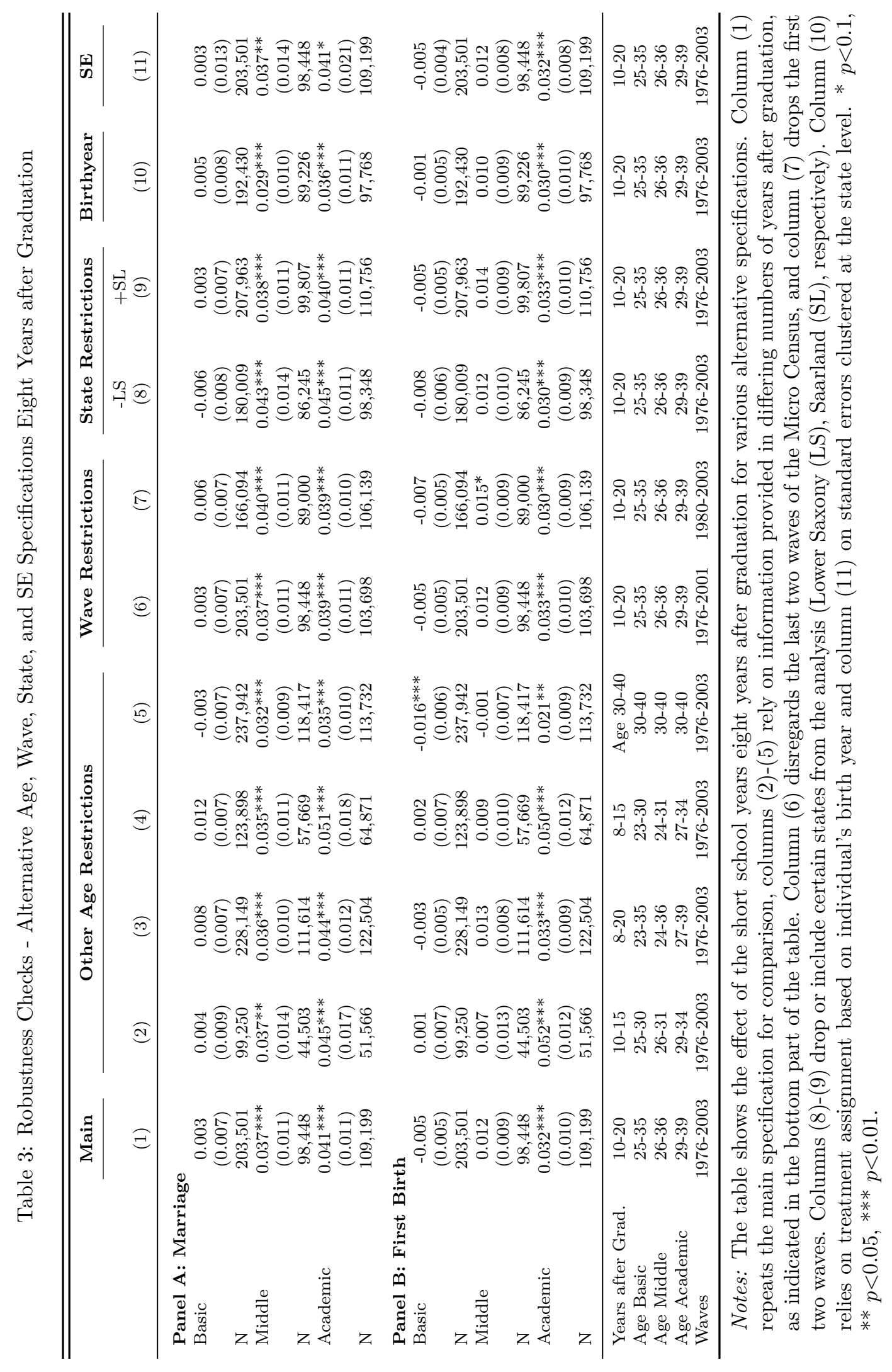


Table 4: Effect Heterogeneity by Gender

\begin{tabular}{|c|c|c|c|c|c|c|}
\hline & \multicolumn{2}{|c|}{5 Years } & \multicolumn{2}{|c|}{8 Years } & \multicolumn{2}{|c|}{10 Years } \\
\hline & $\begin{array}{c}\text { Female } \\
(1)\end{array}$ & $\begin{array}{l}\text { Male } \\
(2)\end{array}$ & $\begin{array}{c}\text { Female } \\
(3)\end{array}$ & $\begin{array}{c}\text { Male } \\
(4)\end{array}$ & $\begin{array}{c}\text { Female } \\
(5)\end{array}$ & $\begin{array}{c}\text { Male } \\
(6)\end{array}$ \\
\hline \multicolumn{7}{|c|}{ Panel A: Marriage } \\
\hline Basic & $\begin{array}{c}0.007 \\
(0.009)\end{array}$ & $\begin{array}{c}0.002 \\
(0.004)\end{array}$ & $\begin{array}{l}-0.004 \\
(0.008)\end{array}$ & $\begin{array}{c}0.009 \\
(0.010)\end{array}$ & $\begin{array}{l}-0.005 \\
(0.008)\end{array}$ & $\begin{array}{c}0.010 \\
(0.011)\end{array}$ \\
\hline $\mathrm{N}$ & 99,685 & 103,816 & 99,685 & 103,816 & 99,685 & 103,816 \\
\hline Middle & $\begin{array}{c}0.054^{* * *} \\
(0.010)\end{array}$ & $\begin{array}{c}0.013 \\
(0.010)\end{array}$ & $\begin{array}{c}0.042^{* * *} \\
(0.013)\end{array}$ & $\begin{array}{c}0.031^{* *} \\
(0.014)\end{array}$ & $\begin{array}{c}0.029^{* * *} \\
(0.011)\end{array}$ & $\begin{array}{c}0.023 \\
(0.016)\end{array}$ \\
\hline $\mathrm{N}$ & 57,381 & 41,067 & 57,381 & 41,067 & 57,381 & 41,067 \\
\hline Academic & $\begin{array}{c}0.035^{* *} \\
(0.014)\end{array}$ & $\begin{array}{c}0.055^{* * *} \\
(0.010)\end{array}$ & $\begin{array}{c}0.029^{* *} \\
(0.014)\end{array}$ & $\begin{array}{c}0.049^{* * *} \\
(0.012)\end{array}$ & $\begin{array}{c}0.015 \\
(0.014)\end{array}$ & $\begin{array}{c}0.033^{* * *} \\
(0.013)\end{array}$ \\
\hline $\mathrm{N}$ & 46,289 & 62,910 & 46,289 & 62,910 & 46,289 & 62,910 \\
\hline \multicolumn{7}{|c|}{ Panel B: First Birth } \\
\hline Basic & $\begin{array}{l}-0.001 \\
(0.006)\end{array}$ & $\begin{array}{c}0.002 \\
(0.003)\end{array}$ & $\begin{array}{c}-0.004 \\
(0.008)\end{array}$ & $\begin{array}{l}-0.005 \\
(0.005)\end{array}$ & $\begin{array}{l}-0.015^{*} \\
(0.008)\end{array}$ & $\begin{array}{l}-0.007 \\
(0.008)\end{array}$ \\
\hline $\mathrm{N}$ & 99,685 & 103,816 & 99,685 & 103,816 & 99,685 & 103,816 \\
\hline Middle & $\begin{array}{c}0.010 \\
(0.007)\end{array}$ & $\begin{array}{c}0.004 \\
(0.006)\end{array}$ & $\begin{array}{c}0.018 \\
(0.011)\end{array}$ & $\begin{array}{c}0.005 \\
(0.010)\end{array}$ & $\begin{array}{l}0.023^{*} \\
(0.013)\end{array}$ & $\begin{array}{c}0.014 \\
(0.013)\end{array}$ \\
\hline $\mathrm{N}$ & 57,381 & 41,067 & 57,381 & 41,067 & 57,381 & 41,067 \\
\hline Academic & $\begin{array}{l}0.022^{*} \\
(0.011)\end{array}$ & $\begin{array}{c}0.012^{* *} \\
(0.006)\end{array}$ & $\begin{array}{c}0.033^{* *} \\
(0.014)\end{array}$ & $\begin{array}{c}0.031^{* * *} \\
(0.009)\end{array}$ & $\begin{array}{c}0.040^{* * *} \\
(0.014)\end{array}$ & $\begin{array}{c}0.033^{* * *} \\
(0.010)\end{array}$ \\
\hline $\mathrm{N}$ & 46,289 & 62,910 & 46,289 & 62,910 & 46,289 & 62,910 \\
\hline
\end{tabular}

Notes: The table shows the effect of the short school years separately for males and females. Standard errors clustered at the cohort-state level in parentheses. $* p<0.1,{ }^{* *} p<0.05, * * * p<0.01$. 
Table 5: Short School Year Effects: Longer Time Horizons

\begin{tabular}{|c|c|c|c|c|c|c|}
\hline & \multicolumn{6}{|c|}{ Years after Graduation } \\
\hline & 10 & 11 & 12 & 13 & 14 & 15 \\
\hline \multicolumn{7}{|c|}{ Panel A: Marriage } \\
\hline Basic & $\begin{array}{c}0.003 \\
(0.008)\end{array}$ & $\begin{array}{l}-0.002 \\
(0.008)\end{array}$ & $\begin{array}{l}-0.004 \\
(0.008)\end{array}$ & $\begin{array}{l}-0.008 \\
(0.009)\end{array}$ & $\begin{array}{l}-0.006 \\
(0.009)\end{array}$ & $\begin{array}{l}-0.008 \\
(0.009)\end{array}$ \\
\hline $\mathrm{N}$ & 203,501 & 188,330 & 173,232 & 157,588 & 140,755 & 122,803 \\
\hline Middle & $\begin{array}{c}0.026^{* *} \\
(0.011)\end{array}$ & $\begin{array}{c}0.022^{* *} \\
(0.009)\end{array}$ & $\begin{array}{l}0.018^{*} \\
(0.010)\end{array}$ & $\begin{array}{c}0.013 \\
(0.009)\end{array}$ & $\begin{array}{c}0.011 \\
(0.010)\end{array}$ & $\begin{array}{c}0.001 \\
(0.009)\end{array}$ \\
\hline $\mathrm{N}$ & 98,448 & 91,869 & 84,934 & 77,690 & 69,823 & 61,960 \\
\hline Academic & $\begin{array}{c}0.025^{* *} \\
(0.011)\end{array}$ & $\begin{array}{c}0.014 \\
(0.010)\end{array}$ & $\begin{array}{c}0.008 \\
(0.009)\end{array}$ & $\begin{array}{c}0.007 \\
(0.009)\end{array}$ & $\begin{array}{l}-0.001 \\
(0.009)\end{array}$ & $\begin{array}{l}-0.008 \\
(0.010)\end{array}$ \\
\hline $\mathrm{N}$ & 109,199 & 101,972 & 94,829 & 87,503 & 78,097 & 68,785 \\
\hline \multicolumn{7}{|c|}{ Panel B: First Birth } \\
\hline Basic & $\begin{array}{c}-0.011^{*} \\
(0.006)\end{array}$ & $\begin{array}{c}-0.015^{* *} \\
(0.006)\end{array}$ & $\begin{array}{l}-0.009 \\
(0.007)\end{array}$ & $\begin{array}{l}-0.008 \\
(0.007)\end{array}$ & $\begin{array}{l}-0.005 \\
(0.007)\end{array}$ & $\begin{array}{c}-0.003 \\
(0.008)\end{array}$ \\
\hline $\mathrm{N}$ & 203,501 & 188,330 & 173,232 & 157,588 & 140,755 & 122,803 \\
\hline Middle & $\begin{array}{l}0.019^{*} \\
(0.011)\end{array}$ & $\begin{array}{c}0.015 \\
(0.011)\end{array}$ & $\begin{array}{l}0.020^{*} \\
(0.011)\end{array}$ & $\begin{array}{c}0.024^{* *} \\
(0.011)\end{array}$ & $\begin{array}{l}0.020^{*} \\
(0.011)\end{array}$ & $\begin{array}{c}0.012 \\
(0.010)\end{array}$ \\
\hline $\mathrm{N}$ & 98,448 & 91,869 & 84,934 & 77,690 & 69,823 & 61,960 \\
\hline Academic & $\begin{array}{c}0.036^{* * *} \\
(0.010)\end{array}$ & $\begin{array}{c}0.031^{* * *} \\
(0.011)\end{array}$ & $\begin{array}{c}0.027^{* *} \\
(0.011)\end{array}$ & $\begin{array}{c}0.025^{* *} \\
(0.011)\end{array}$ & $\begin{array}{c}0.020 \\
(0.013)\end{array}$ & $\begin{array}{c}0.017 \\
(0.013)\end{array}$ \\
\hline $\mathrm{N}$ & 109,199 & 101,972 & 94,829 & 87,503 & 78,097 & 68,785 \\
\hline
\end{tabular}

Notes: The table shows the effect of the short school years on marriage and first birth ten to fifteen years after graduation from secondary school for individuals in different secondary school tracks based on Equation (2). Standard errors clustered at the cohort-state level in parentheses. ${ }^{*} p<0.1$, ** $p<0.05,{ }^{* * *} p<0.01$. 


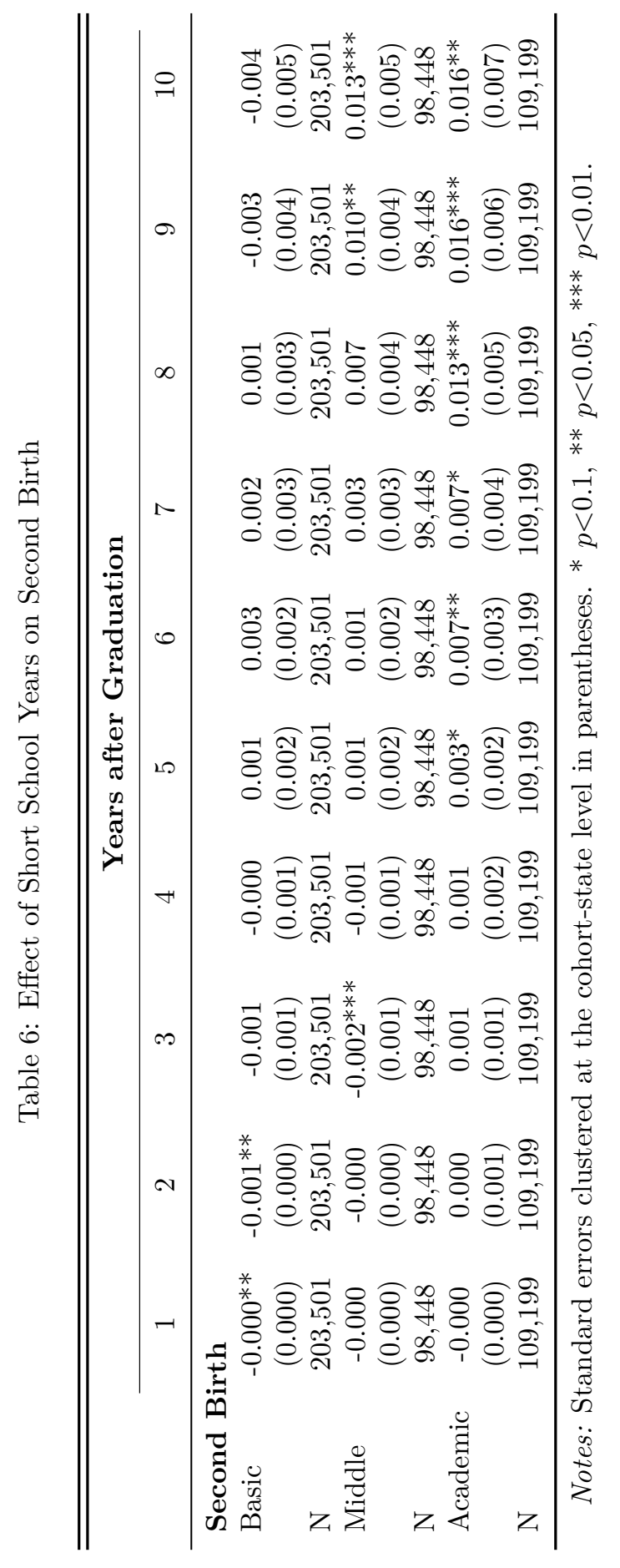




\section{A. Appendix A: Additional Robustness Checks and Further Results}

Figure A.1: Probability of Marriage and First Birth by Years after Graduation and Gender

(a) Marriage - Basic

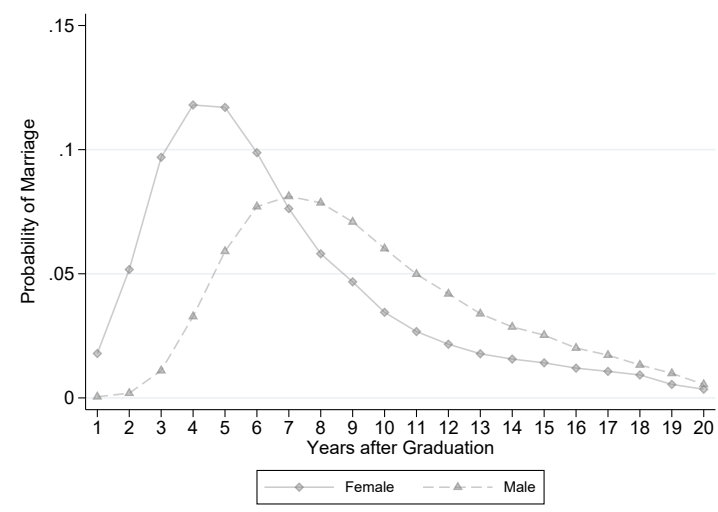

(c) Marriage - Middle

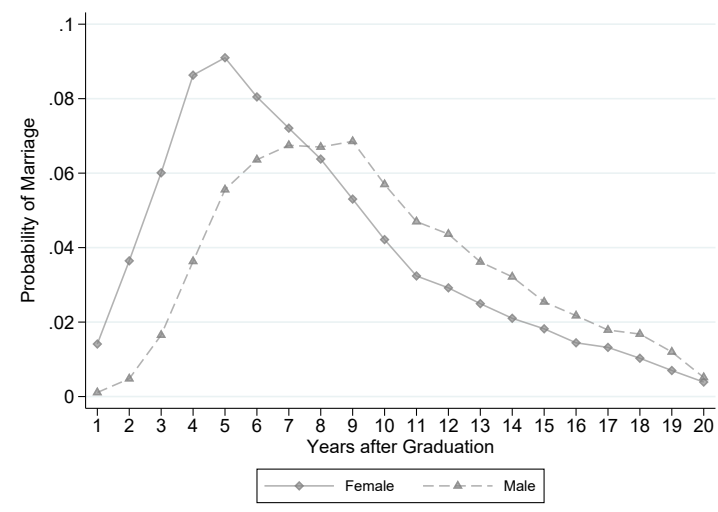

(e) Marriage - Academic

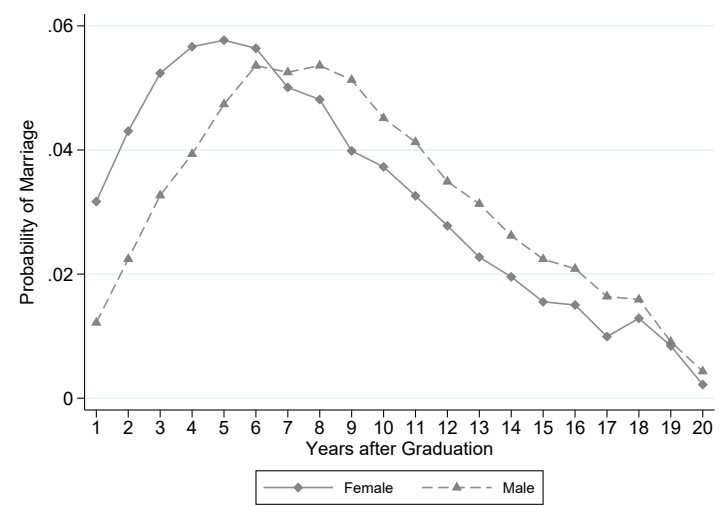

(b) First Birth - Basic

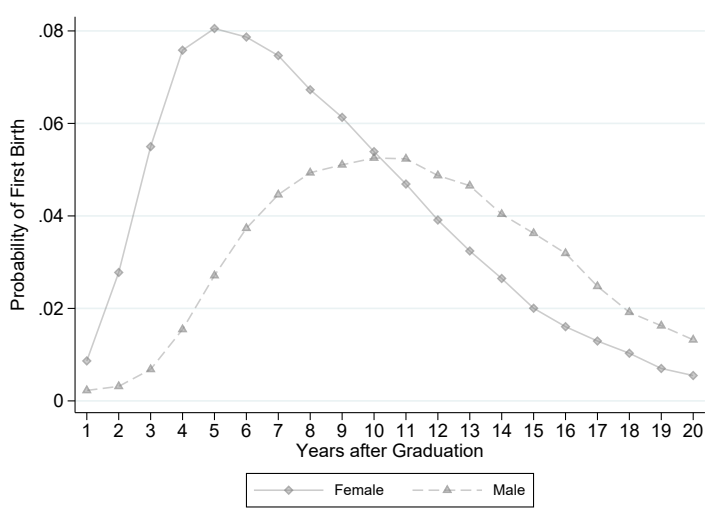

(d) First Birth - Middle

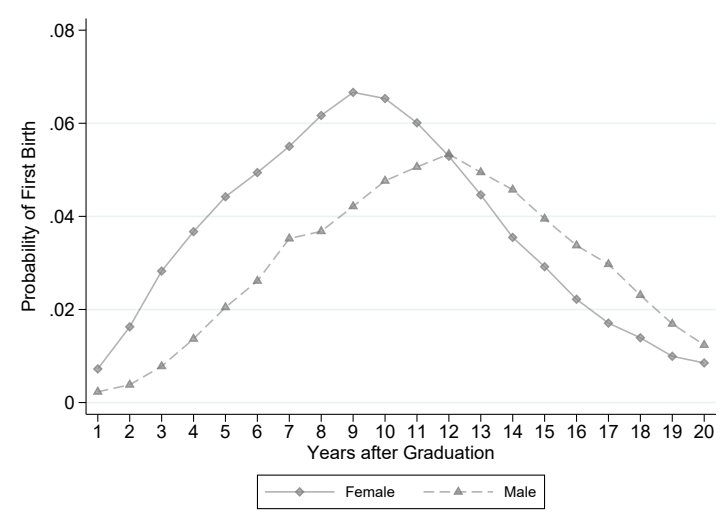

(f) First Birth - Academic

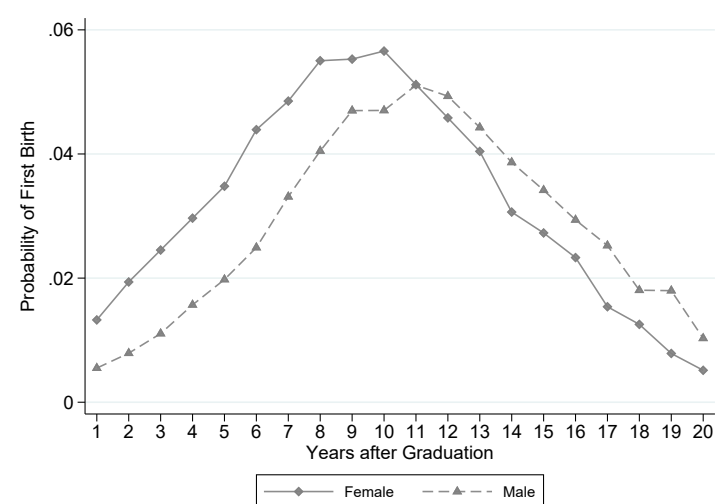


Table A.1: Effect of Short School Years on Wage and Employment

\begin{tabular}{lccc}
\hline \hline & Main & & Male \\
& $(1)$ & & $(2)$ \\
\hline Panel A: Wage & & \\
Pischke (2007) & 0.017 & & 0.001 \\
$\mathrm{~N}$ & $(0.011)$ & & $(0.011)$ \\
Replication & 723,470 & & 430,859 \\
& 0.014 & & -0.007 \\
$\mathrm{~N}$ & $(0.014)$ & & $(0.015)$ \\
Panel B: Employment & \\
Pischke (2007) & $0.016^{* * *}$ & $0.013^{*}$ \\
$\mathrm{~N}$ & $(0.006)$ & $(0.007)$ \\
$\mathrm{N}$ & $1,032,744$ & 509,770 \\
Replication & $0.020^{* *}$ & $0.015^{*}$ \\
\multicolumn{2}{l}{$\mathrm{N}$} & $(0.008)$ & $(0.009)$ \\
$\mathrm{N}$ & $1,071,256$ & 536,235 \\
\hline
\end{tabular}

Notes: This table replicates wage and employment regressions using the same sample and wave restrictions as specified in Pischke (2007). Exposure to short school years is assigned according to secondary school track, birth cohort (1943-1964), and state of residence. The first row of each Panel displays estimation results taken from Table 5 and Table 8 in Pischke (2007), respectively. In Panel $\mathrm{A}$, the dependent variable is the log hourly wage, in Panel B a dummy for being employed in the survey week. Standard errors in parentheses are adjusted at the track $\mathrm{x}$ birth year $\mathrm{x}$ state level. 


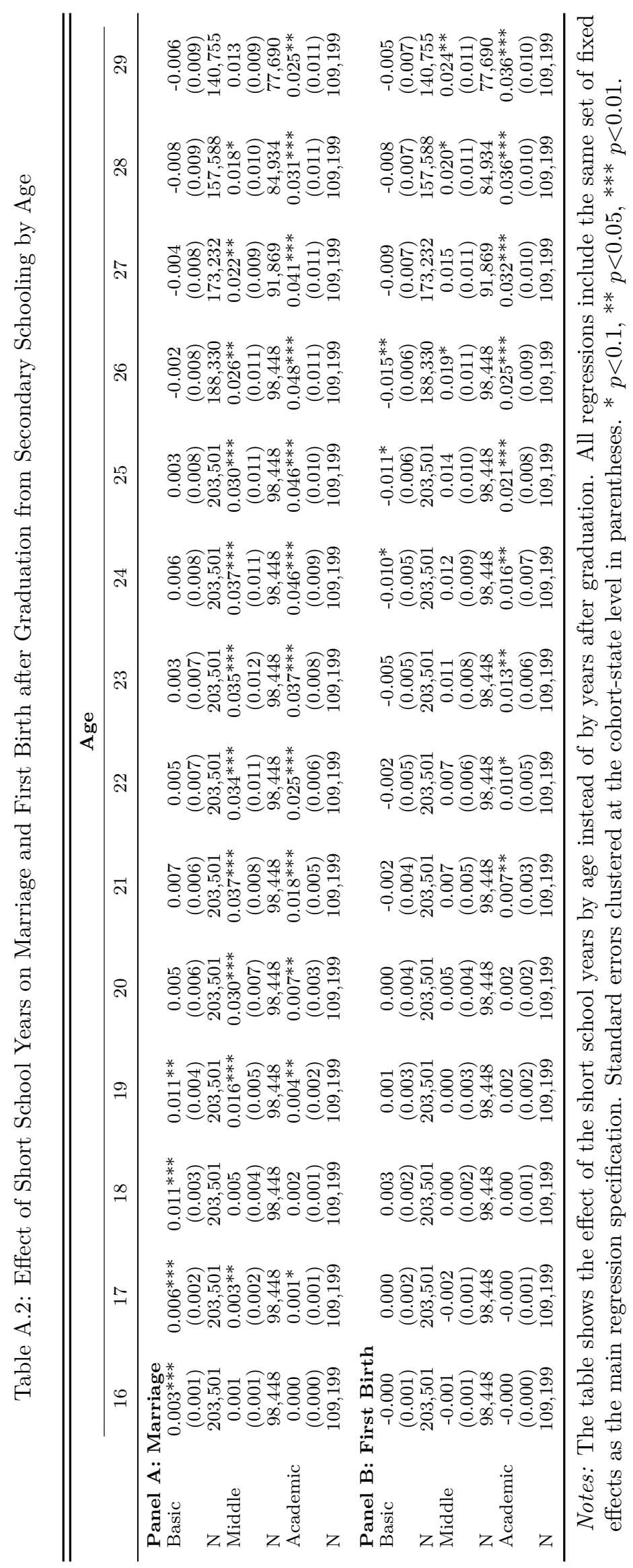




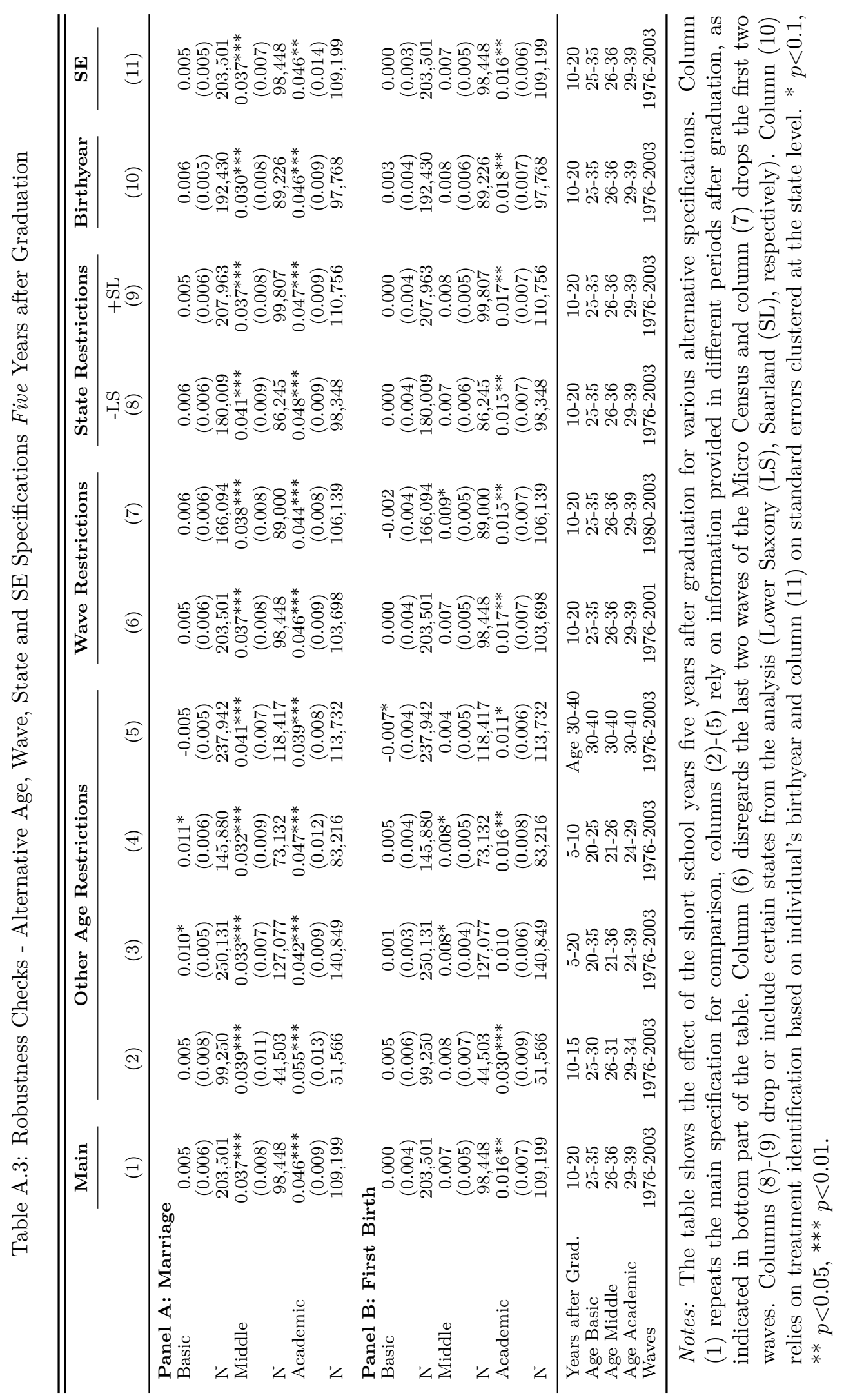




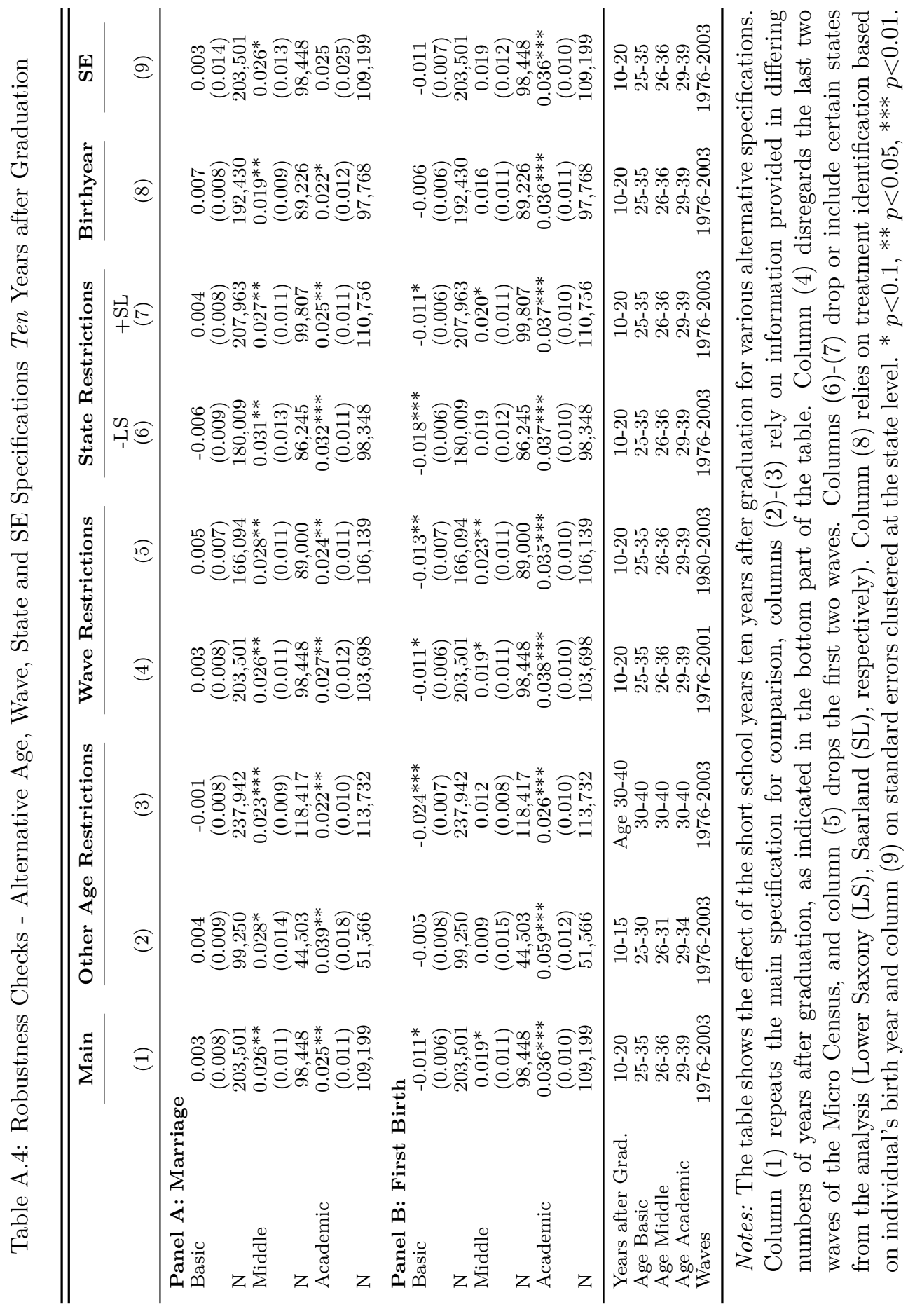




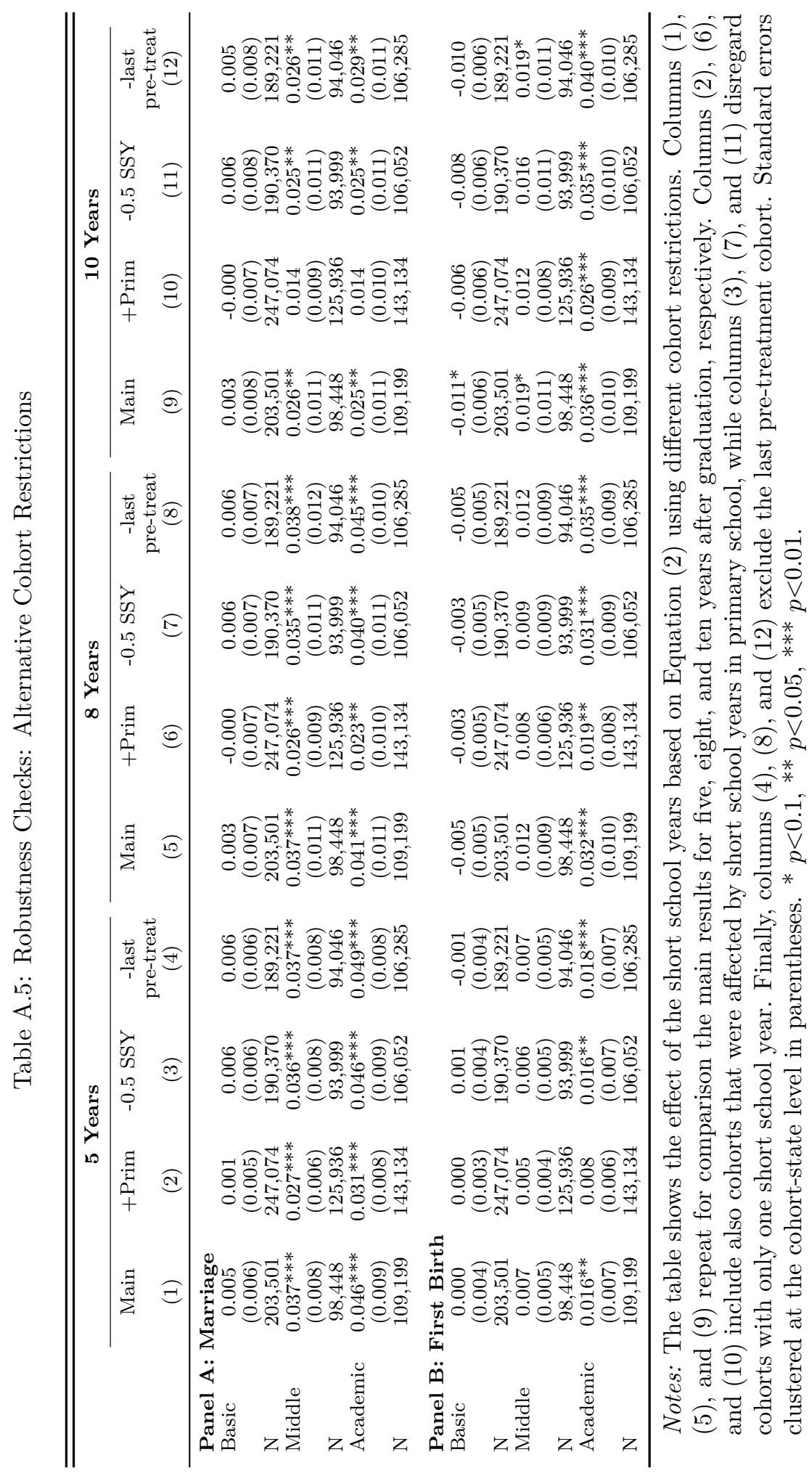


Table A.6: Controlling for Compulsory Schooling (CS) Reforms

\begin{tabular}{lcccc}
\hline \hline & Main & \multicolumn{2}{c}{ CS Control } \\
\cline { 2 - 3 } & $(1)$ & $(2)$ & $(3)$ \\
\hline \multicolumn{2}{l}{ Panel A: Marriage - Basic Track } & & \\
5 Years after Graduation & 0.005 & -0.001 & 0.005 \\
& $(0.006)$ & $(0.006)$ & $(0.007)$ \\
8 Years after Graduation & 0.003 & -0.006 & -0.006 \\
& $(0.007)$ & $(0.008)$ & $(0.007)$ \\
10 Years after Graduation & 0.003 & -0.007 & -0.008 \\
& $(0.008)$ & $(0.009)$ & $(0.008)$ \\
N & 203,501 & 203,501 & 203,501 \\
Panel B: First Birth - Basic Track & & \\
5 Years after Graduation & 0.000 & -0.000 & -0.001 \\
& $(0.004)$ & $(0.004)$ & $(0.004)$ \\
8 Years after Graduation & -0.005 & -0.004 & -0.007 \\
& $(0.005)$ & $(0.006)$ & $(0.005)$ \\
10 Years after Graduation & $-0.011^{*}$ & -0.009 & $-0.014 * *$ \\
& $(0.006)$ & $(0.007)$ & $(0.007)$ \\
N & 203,501 & 203,501 & 203,501 \\
\hline No CS Control & Yes & No & No \\
CS Control Refined & No & Yes & No \\
CS Control Pischke $(2007)$ & No & No & Yes \\
\hline
\end{tabular}

Notes: The table shows the effect of the short school years on marriage and first birth five, eight, and ten years after graduation for individuals in the basic track, without controlling for compulsory schooling reforms (column 1), controlling for compulsory schooling reforms according to our refined dates (column 2), and the reform dates used by Pischke (2007) in column (3). The latter reform dates coincide with reform dates used in Pischke and von Wachter (2005, 2008). Standard errors clustered at the cohort-state level in parentheses. ${ }^{*} p<0.1,{ }^{* *} p<0.05,{ }^{* * *}$ $p<0.01$. 


\section{B. Appendix B: Collection of Relevant Schooling Laws for Refined Assignment to Short School Years}

This paper exploits changes in the length of the schooling phase induced by short school years. Therefore, Tables B.1 - B.11 list for students from each West German state and the birth years 1935 through 1965 the regular duration of the schooling phase depending on their secondary school track (columns (8) for basic, (11) for middle, (14) for academic). Based on these numbers, Figure B.1 graphically depicts the development of the regular length of schooling across cohorts for all West German states and tracks.

Tables B.1 - B.11 exhibit three other noteworthy features. First, they provide the necessary information for the computation of the regular duration of the schooling phase (see below). Second, the tables list the relevant legal sources, which we display in detail in Table B.12 ${ }^{20}$ Third, the tables mark the SSY treatment status and the cohorts included in the main analyses (columns (6), (9), and (12)).

Regarding the first point: For an individual in a given state and track, the regular duration of the schooling phase depends on the individual's birth year and month (columns (1) and (2)), the legal age cut-off date for school entry (column (3)), and the subsequent date of school entry (column (4)). Besides the short school years in 1966/67 (columns (6), (9), and (12)), there are two other sources of institutional variation affecting the regular length of the schooling phase. First, several states moved the start of the school year from fall to Easter in line with the Düsseldorf Accord (DA) in 1955. These changes are considered in the computation of the regular school duration as well and the respective law sources are listed in law column (17) of Tables B.1 - B.11. Cohorts affected by these changes are generally excluded from our analyses (see also Section 3.3 and the dashed lines in Figure B.1, which indicate deviations from the time windows used in Pischke (2007) and Braakmann (2010)).

Second, the basic track was extended from eight to nine years between World War II and the SSY introduction in different West German states at different points in time (columns 5). In the states of Baden-Württemberg, North-Rhine-Palatine, Rhineland-Palatine, and Hesse, the introduction of a mandatory ninth grade coincided with the implementation of short school years. In these states but Hesse, instead of adding an extra year of schooling to graduating classes in order to fulfill the new minimum of nine years of schooling, students had to attend two short school years. As a result, these students who would have graduated regularly after eight years at Easter 1967 stayed in school until fall 1967. Hence, the net

\footnotetext{
${ }^{20}$ In all tables, law sources are stated in columns (15)-(18) and compiled in Table B.12 in case of changes concerning school-entry cut-off rules, compulsory schooling (CPS), or start of the school year reforms - either in line with the Düsseldorf Accord (DA) or with the Hamburg Accord (HA).
} 
effect for these affected cohorts was an increase in time spent in school compared to previous cohorts (four months longer), but less of an increase relative to states for which the change in compulsory schooling implied an increase of a full year of schooling. In the state of Hesse, implementation of an additional school year took place with the first short school year. As a result, students who entered school in April 1958 would have graduated after eight years in March 1966 but had to attend one additional school year and thus, the first short school year before graduating in November 1966 after eight years and eight months time of instruction.

Several economic studies exploit these increases in compulsory years of schooling in Germany as an instrument for education. The literature mainly uses two sets of compulsory schooling reform dates; reform years initially proposed in the study by Pischke and von Wachter (2005, 2008) ${ }^{21}$ and a second set referring to a book chapter by Leschinsky and Roeder (1980) with slightly different reform dates used in studies by e.g. Piopiunik 2011, 2014). For the former set of reform years, the authors do not specify any primary sources for the applied reform dates, which is also pointed out in Helbig and Nikolai (2015, p.62). ${ }^{22}$ We propose a refined set of reform years based on a comprehensive collection of educational laws as primary sources for regulating compulsory schooling in each federal state ${ }^{23}$ We thereby corroborate the second set of reform dates and also take age cut-offs for primary school enrolment into account 24 In Saarland, the school year was prolonged to eight years and eight months due to the change of school year start in 1958 (SL58 in Table B.12), and as the statistical year book (issue 1967) does not show a double graduating class in 1965

\footnotetext{
${ }^{21}$ Studies applying the respective reform set include e.g. Siedler (2010); Fort et al. (2011); Kemptner et al. (2011); Huebener (2019); Margaryan et al. (2020).

${ }^{22}$ Furthermore, studies also vary with respect to assigning birth cohorts that were first to experience longer compulsory schooling. Most studies use a school start in the year children turn six or seven. None of these studies take into consideration that the legal age cut-offs determining binding school starts vary on the federal level.

${ }^{23}$ Our legal sources largely coincide with sources collected in Helbig and Nikolai (2015, p.61 ff), but in addition include reform dates for the states of Bremen, Hamburg, and West Berlin; for all three of which Helbig and Nikolai (2015) assign a mandatory ninth school year before the start of their analysis in 1949. However, for the city-state of Bremen, we find that even though HB49 (in Table B.12) establishes compulsory schooling of nine years of schooling, implementation depended on a separate resolution of the Senate, which never appeared. Consequently, we assign the compulsory schooling reform according to HB57 to the school starting cohort 1951 as the first cohort to attend nine years of basic track schooling and graduate at Easter 1960. For the state of Baden-Württemberg, we also deviate from Helbig and Nikolai (2015), as BW66 (in Table B.12 clearly states the joint implementation of a ninth grade with the second short school year.

${ }^{24} \mathrm{We}$ compared and discussed the results of our background research on the reform dates with Kamila Cygan-Rehm, who simultaneously and independently conducted institutional research on this issue for continuing research projects building on Cygan-Rehm (2018). Hampf (2019) and Bömmel and Heineck (2020) also use this set of reform dates.
} 
German Federal Statistical Office (1973), we interpret the year of 1958 as reform year that introduced a ninth school year.

Reading help: The first line of Table B.1 (West Berlin) shows that for individuals of the 1935 birth cohort (1) the relevant cut-off for school entry was December 31st (3). Children started school in August 1941 (4), for basic track students compulsory schooling was nine years (5) and they did not have any short school years (6). Consequently, their regular graduation point was July 1950 (7) after nine years of school (8). The "-" in column (6) indicates that these individuals are neither part of the treatment group nor of the control group in our main analysis. Similarly, individuals in the middle track are not part of our main sample (9). Their regular graduation time was July 1951 (10) after 10 years of schooling (11). Individuals in the academic track regularly finished school in March 1954 (13), after 12.67 school years (14). They did not spend a full 13 years in school due to the moving the start of the school year from fall to Easter in line with the Düsseldorf Accord. Columns (15)(18) display abbreviations of the relevant law sources that can be looked up in Table B.12. Columns (15) and (16) indicate the first school starting cohort that was affected by changes in the cut-off for school entry and compulsory schooling, respectively. Columns (17) and (18) indicate all cohorts that are affected by shorter school years due to Düsseldorf Accord and Hamburg Accord, respectively. 
Figure B.1: Refined Assignment to Short School Years

(a) Berlin

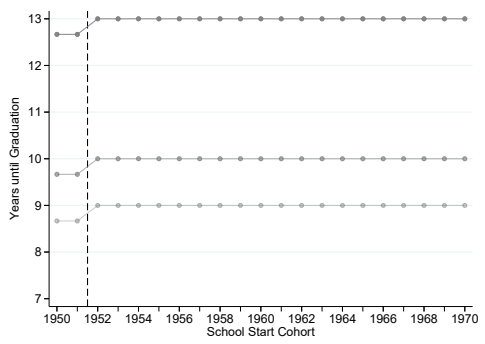

(d) Bremen

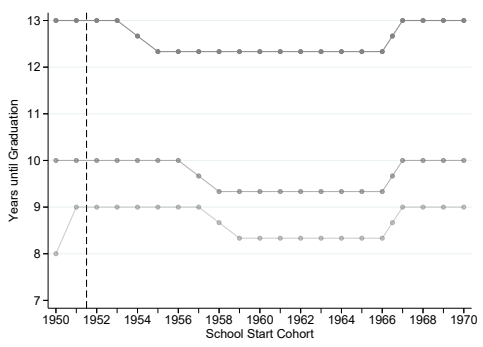

(g) Lower Saxony

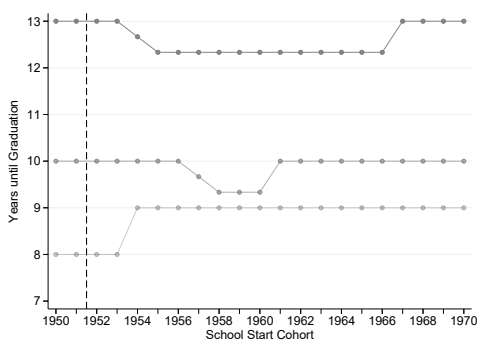

(j) Saarland

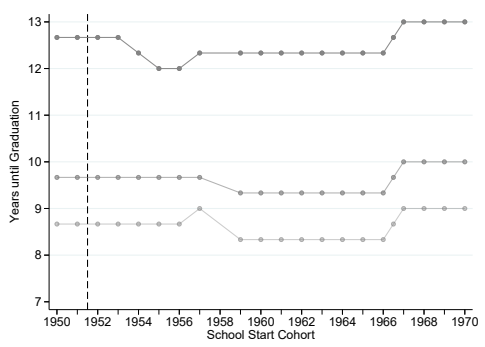

(b) Baden-Württemberg

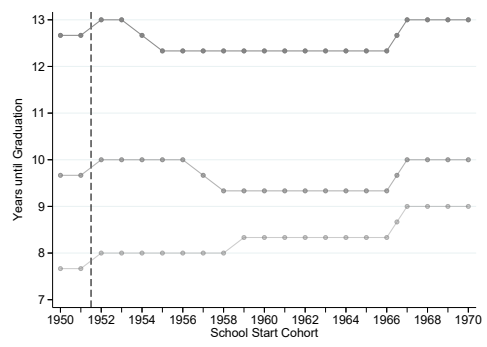

(e) Hamburg

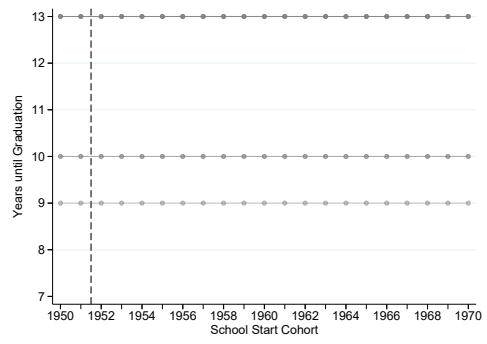

(h) North Rhine-Westphalia

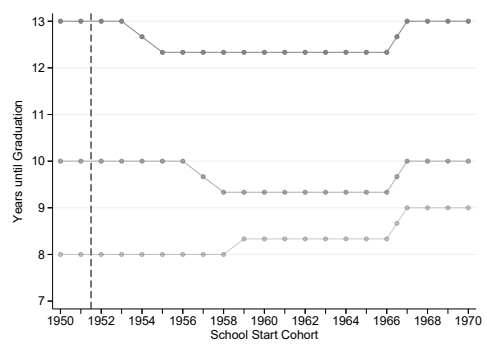

(k) Schleswig-Holstein

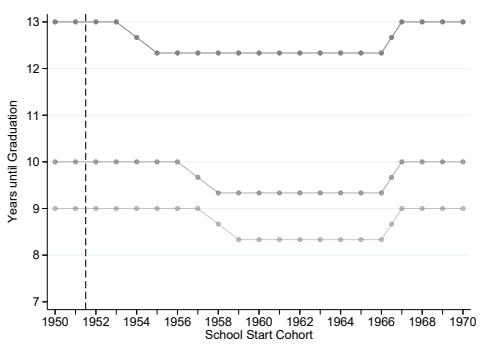

(c) Bavaria

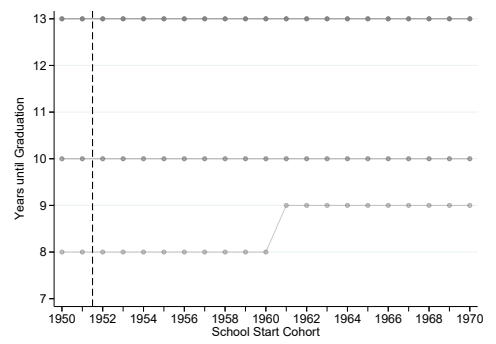

(f) Hesse

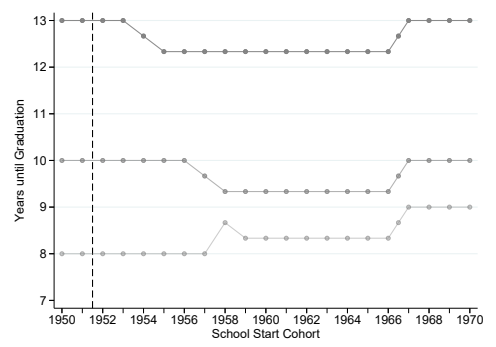

(i) Rhineland-Palatine

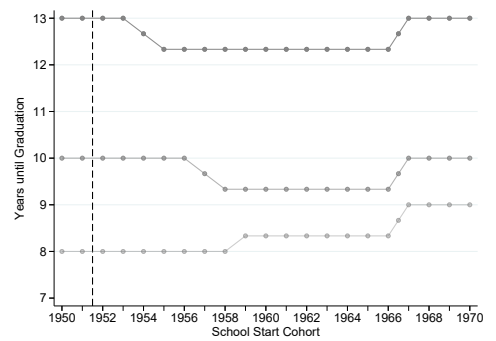

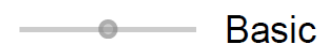

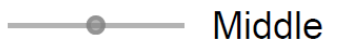

\section{Academic}

Notes: This figure visualizes the proposed refined assignment to short school years for each West German federal state and school track based on individuals' regular duration of the schooling phase (see also columns (8) for basic, (11) for middle, and (14) for academic in Tables B.1.B.11. Narrowing the sample window by two years compared to the setting applied in Pischke (2007) and Braakmann (2010) (as indicated by the dashed lines) and excluding Saarland from our analysis allows us to abstain from using school cohorts that have experienced shorter school years due to earlier shifts of the school starting year from fall to Easter as control units (as in Baden-Württemberg, Bremen, Saarland and West Berlin). Hence, within our sample period using school starting years from 1952 until 1970, deviations from the regular school years required in each track (8/9 years in basic, 10 in middle and 13 in academic) imply exposure to short school years. Own calculations and graphical display. 


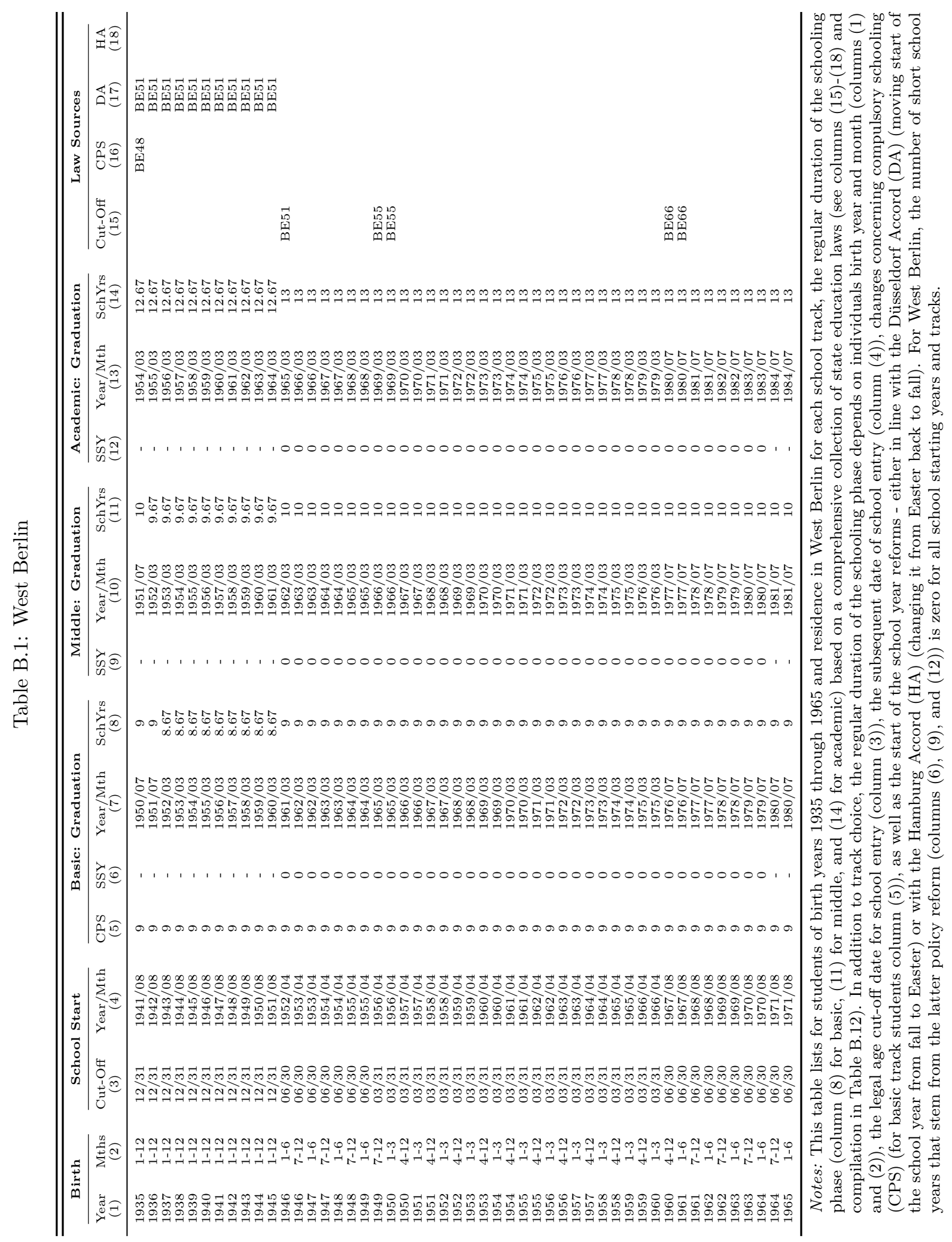




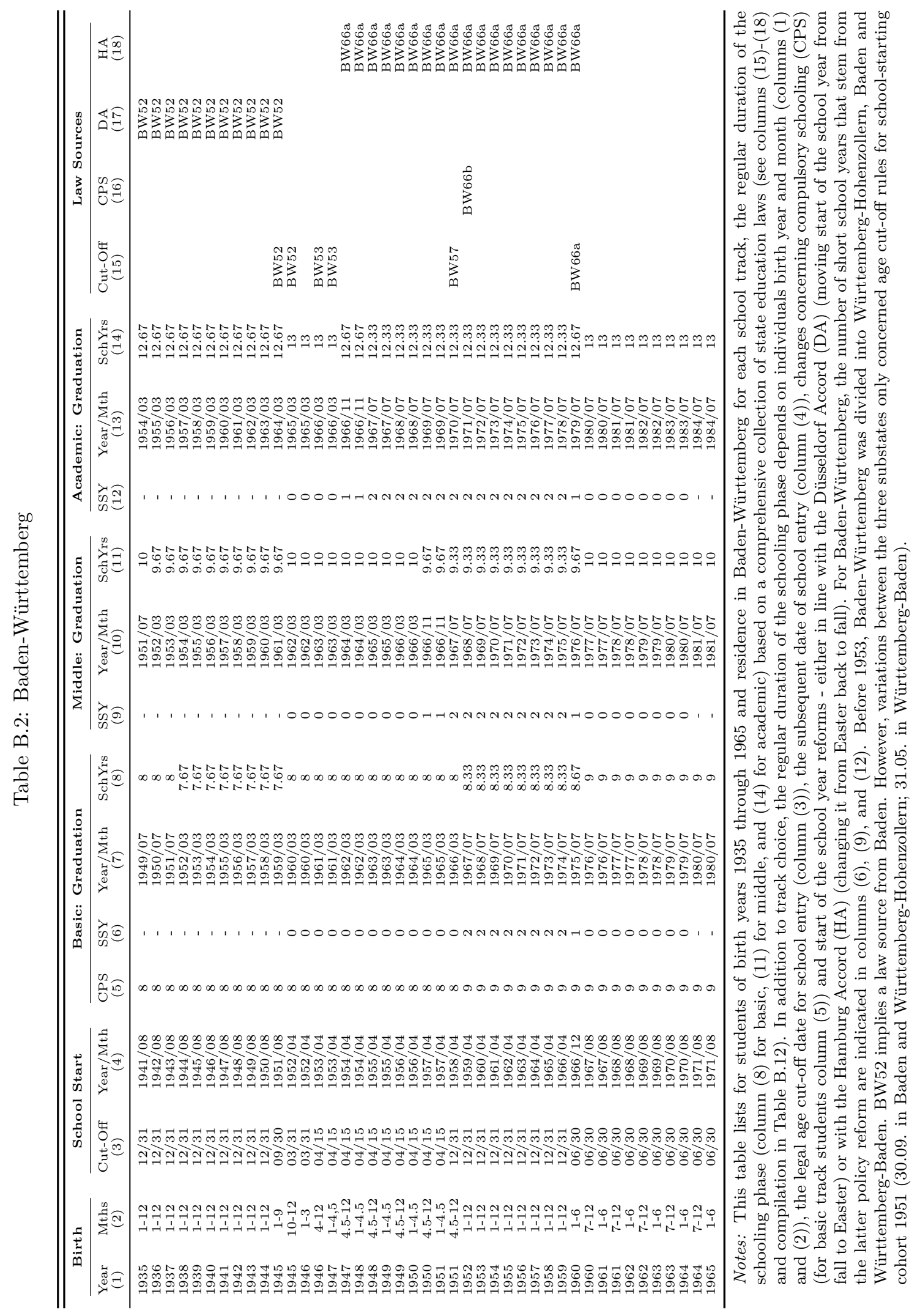




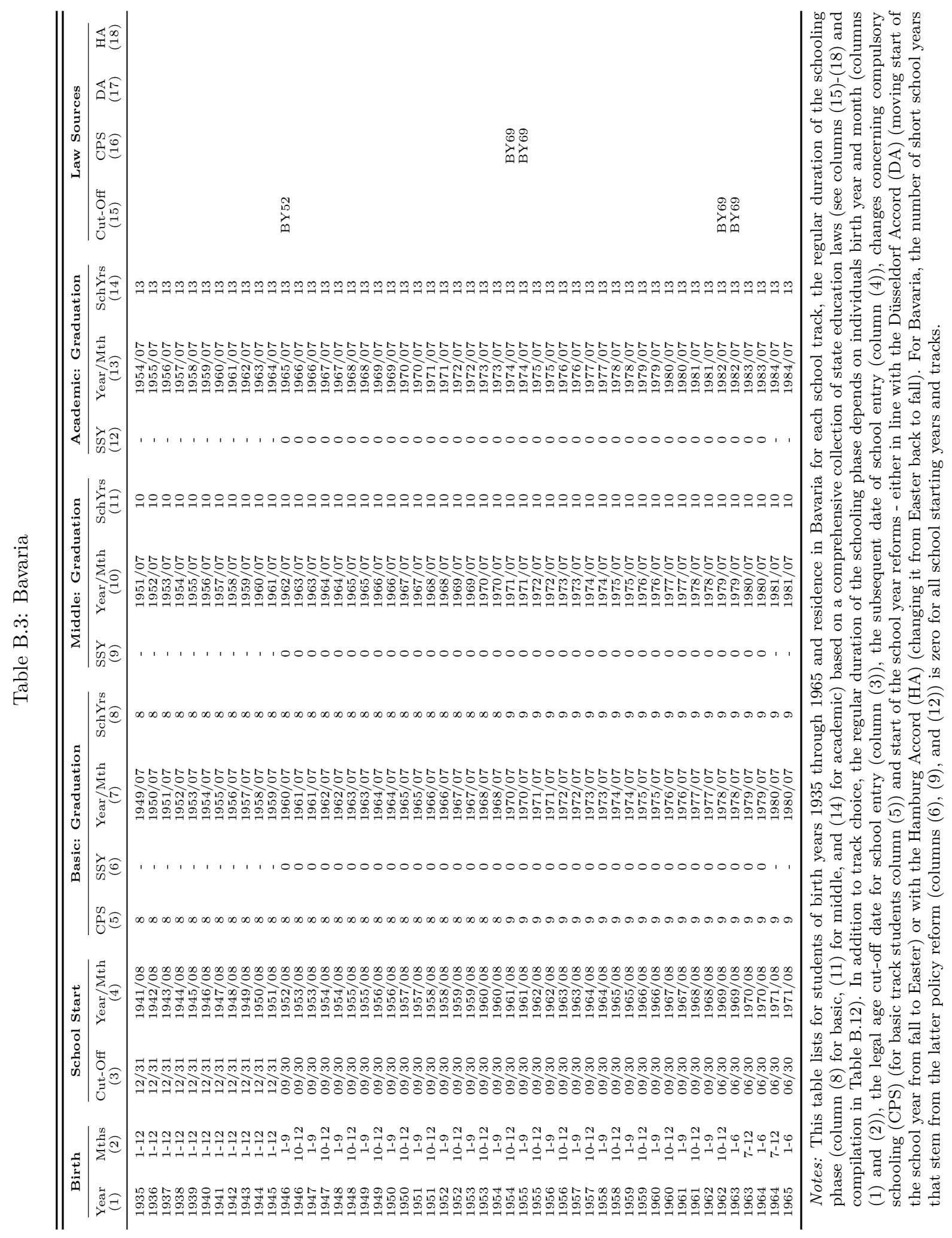




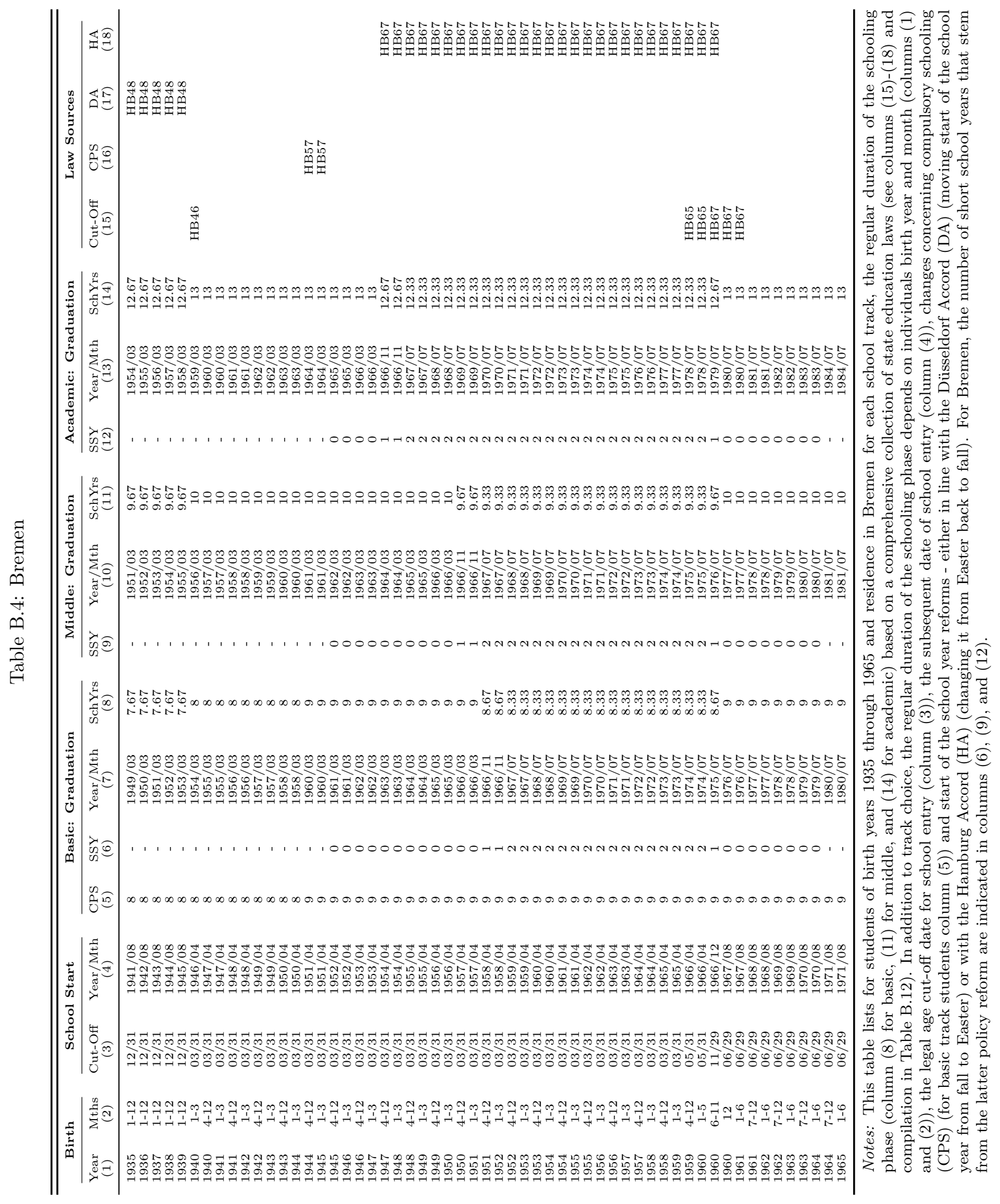




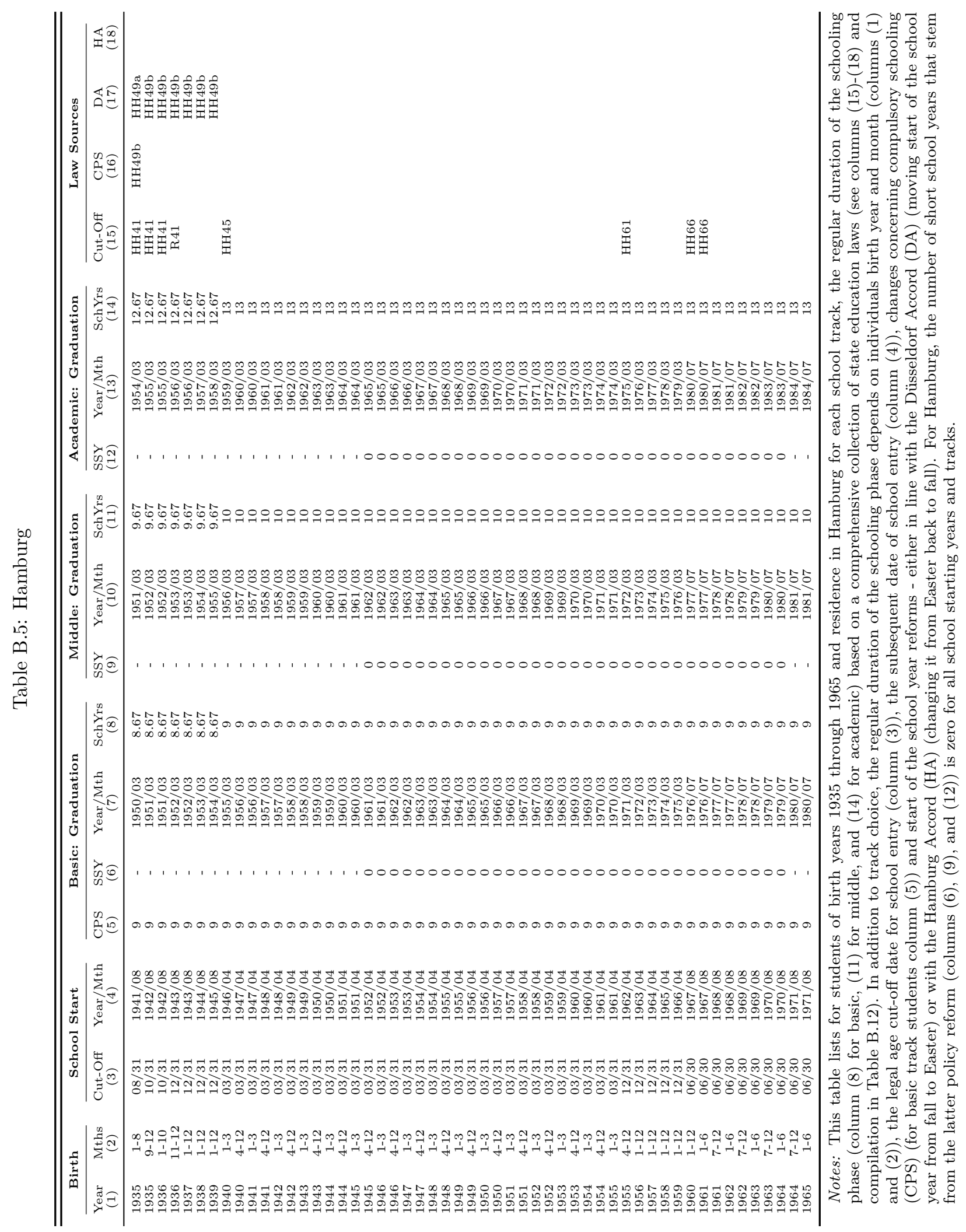




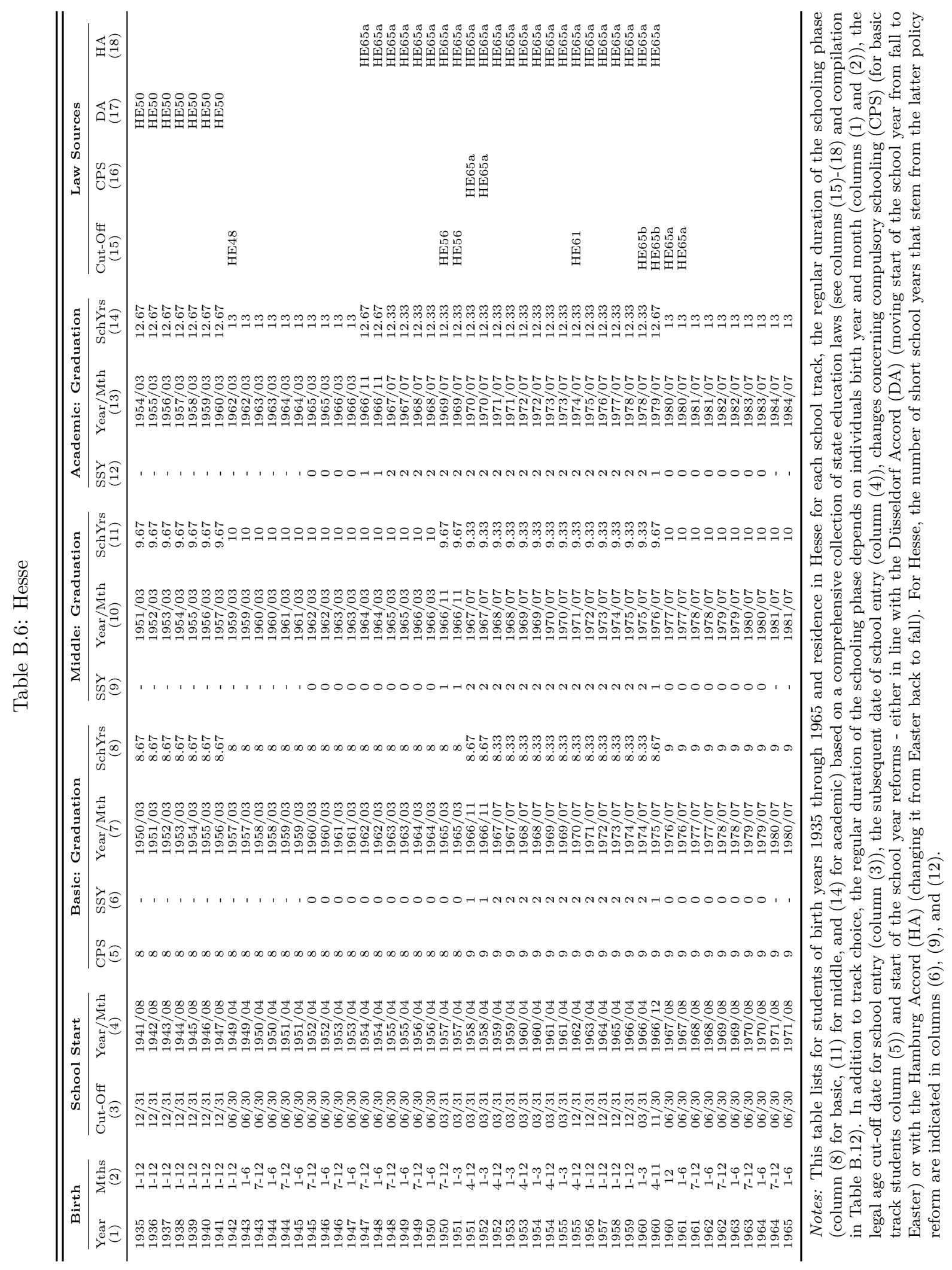




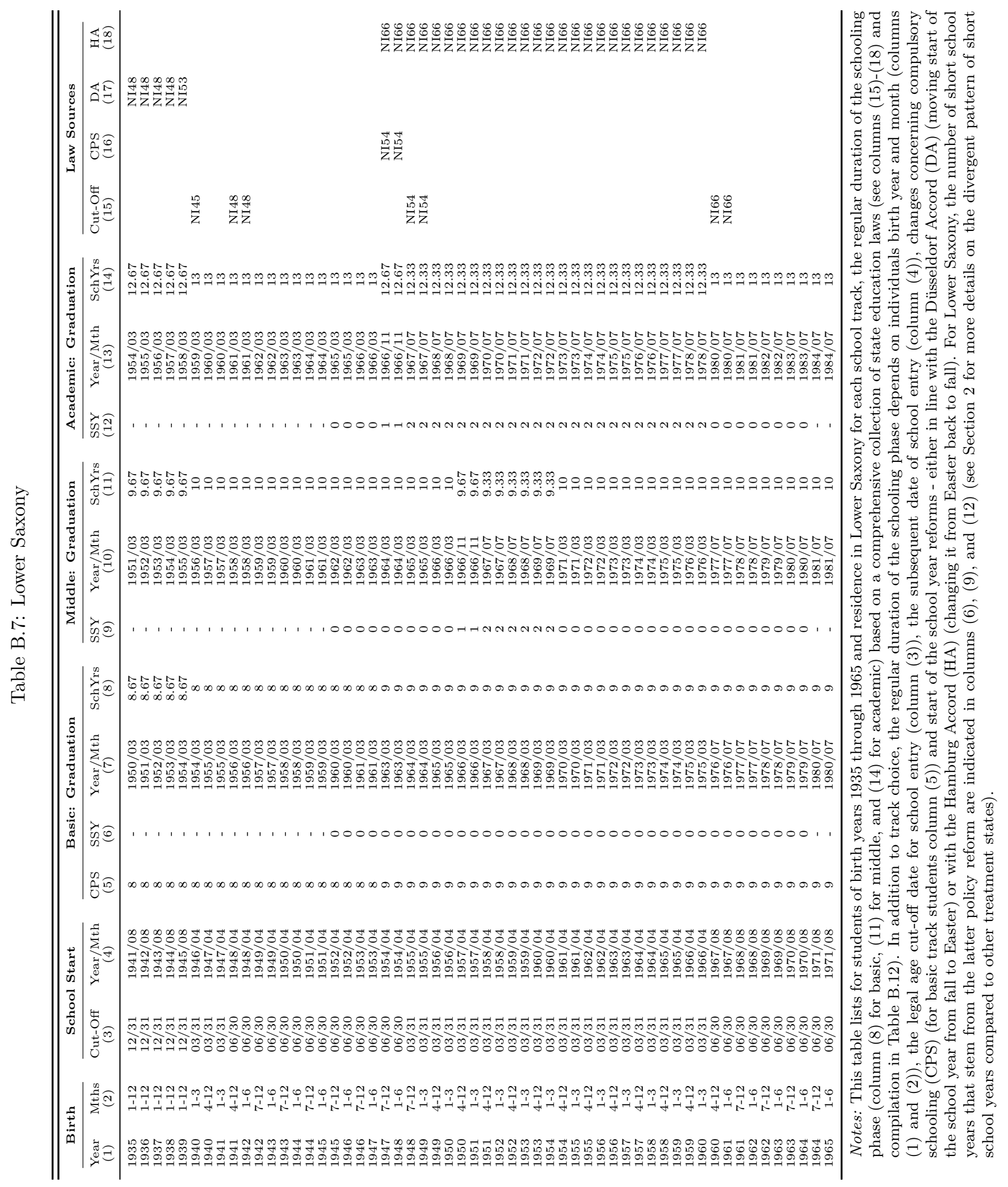




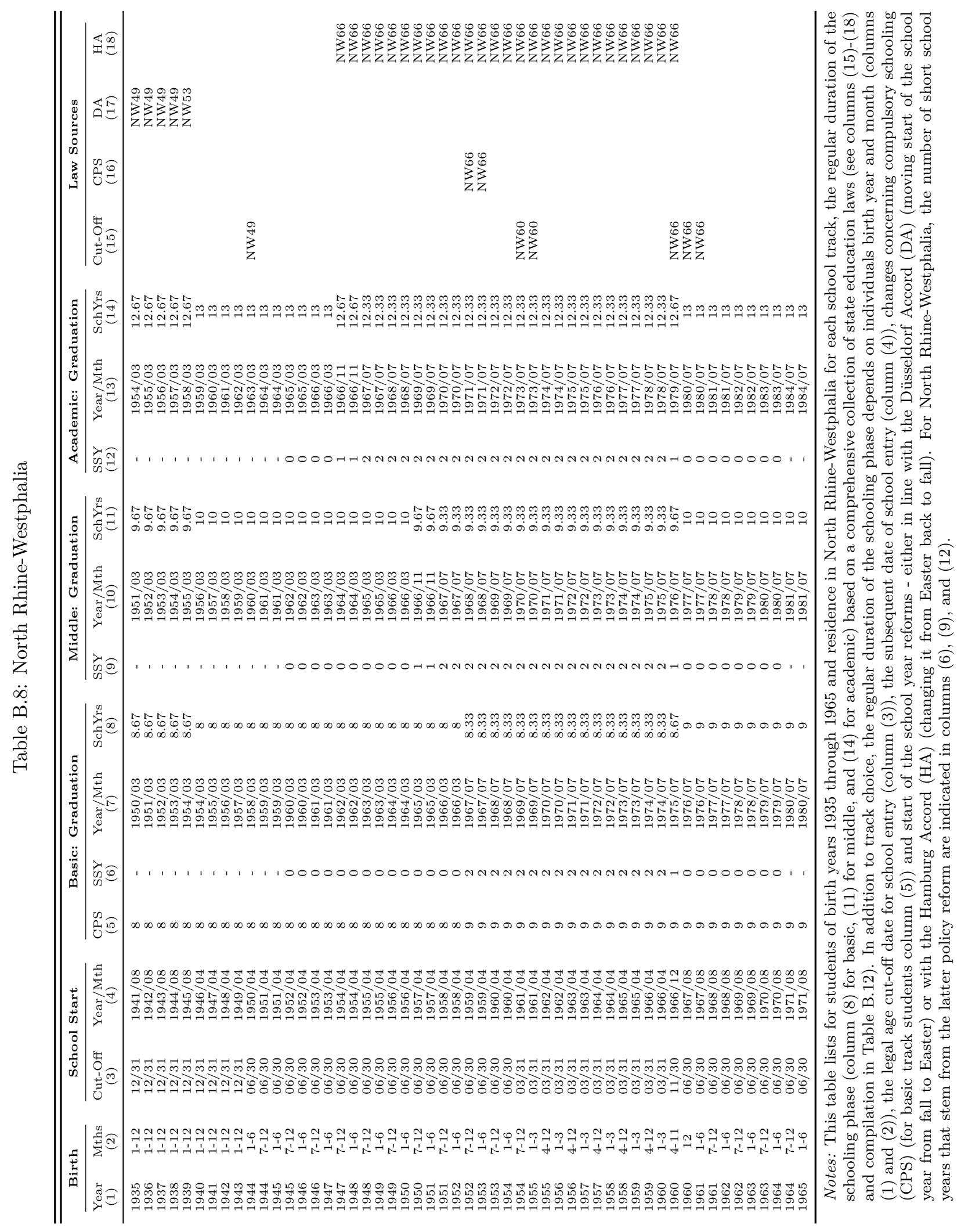




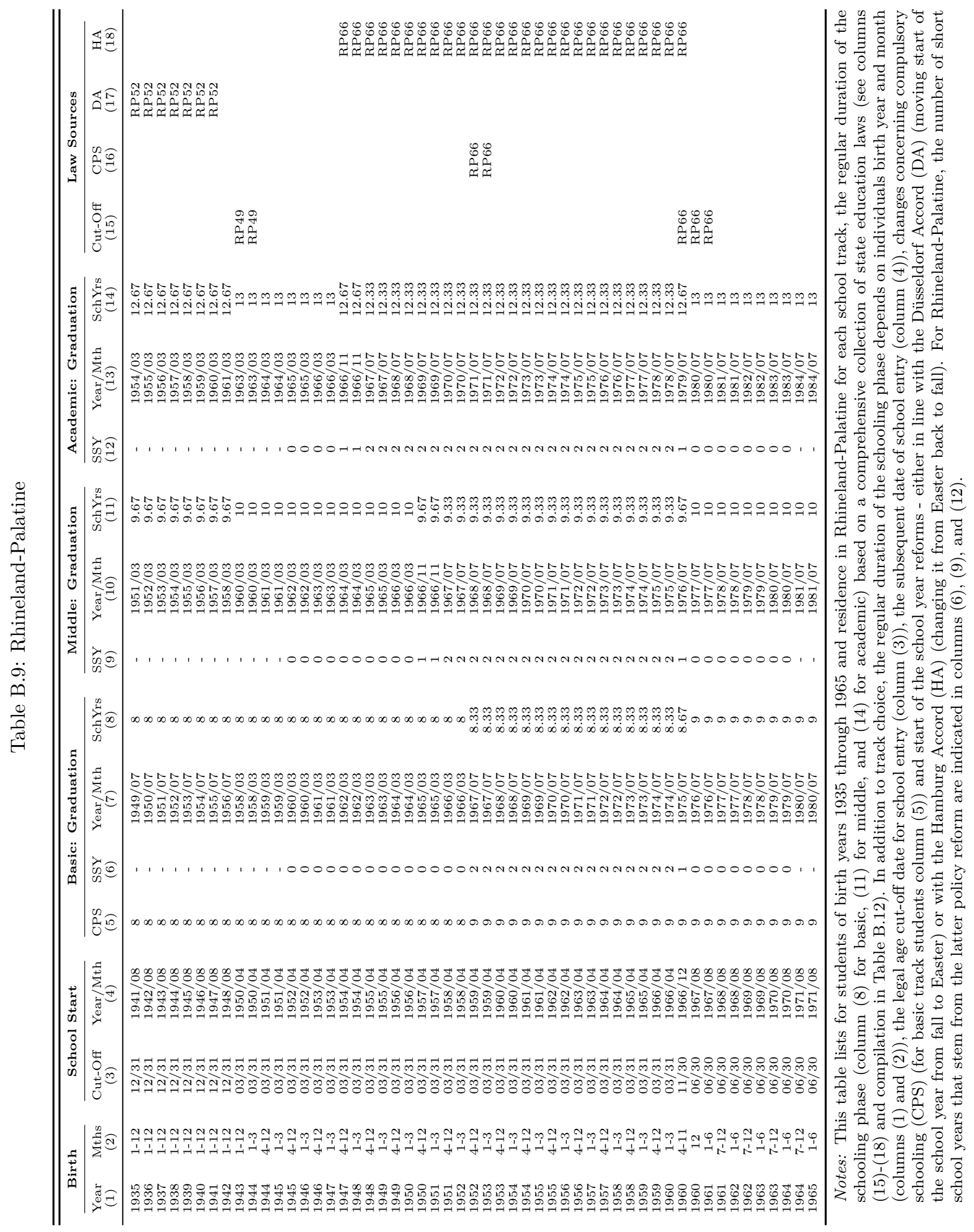




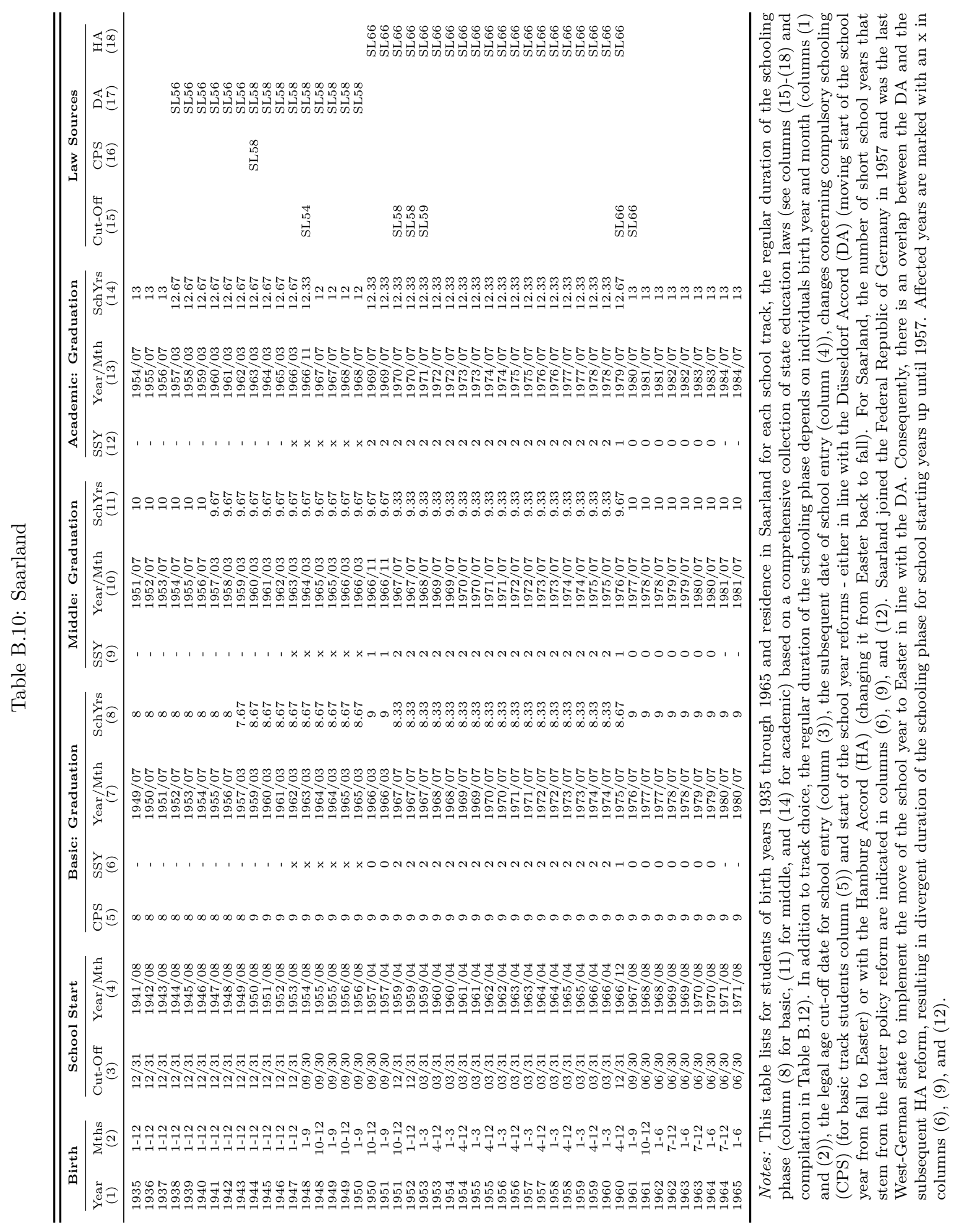




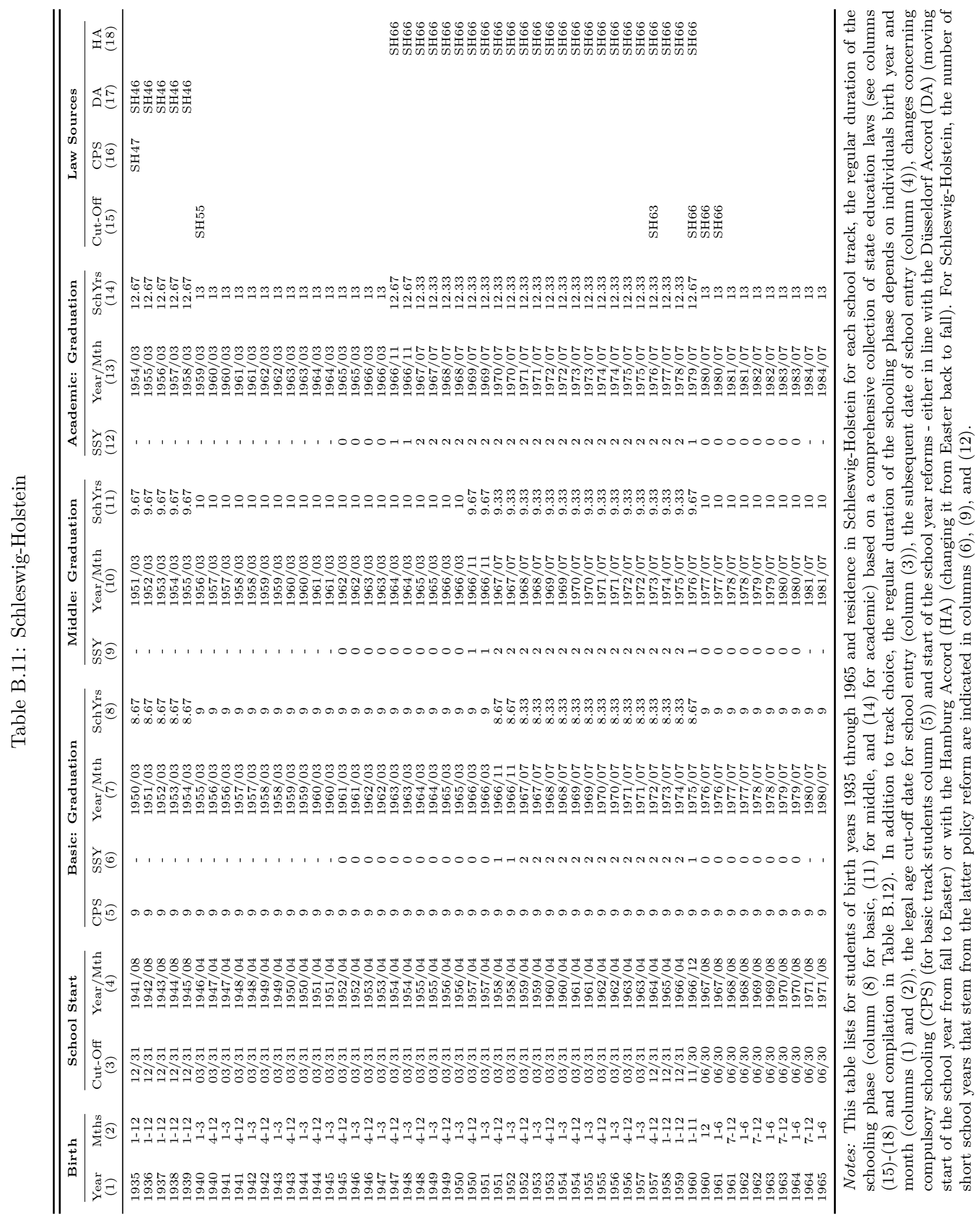


Table B.12: Law Sources Overview

\begin{tabular}{|c|c|c|c|c|c|}
\hline Abbr. & Type & Title & Date & Source & Link \\
\hline \multicolumn{6}{|l|}{ Berlin } \\
\hline BE48 & Erstfassung & Schulgesetz für Groß-Berlin & 26.06 .1948 & VOBl. I 1948, 358 & Link \\
\hline BE51 & Erstfassung & $\begin{array}{l}\text { Dritte Durchführungsverordnung zum Schulgesetz } \\
\text { für Berlin }\end{array}$ & 13.12 .1951 & GVBl. 1951, 1147 & Link \\
\hline BE55 & Änderung & $\begin{array}{l}\text { Drittes Gesetz zur Änderung des Schulgesetzes für } \\
\text { Berlin }\end{array}$ & 09.08 .1955 & GVBl. 1955, 723 & Link \\
\hline BE66 & Neufassung & $\begin{array}{l}\text { Bekanntmachung der Neufassung des } \\
\text { Schulgesetzes für Berlin }\end{array}$ & 13.09.1966 & GVBl. 1966, 1485 & Link \\
\hline \multicolumn{6}{|c|}{ Baden-Württemberg } \\
\hline BW52 & Erstfassung & $\begin{array}{l}\text { Das badische Landesgesetz über Schuljahranfang } \\
\text { und Beginn der Schulpflicht vom } 12.2 .1952\end{array}$ & 12.02 .1952 & GVBl. 1952,25 & \\
\hline BW53 & Neufassung & Gesetz über Schuljahr und Schulpflicht & 09.03 .1953 & GBl. 1953,17 & Link \\
\hline BW57 & Änderung & $\begin{array}{l}\text { Gesetz zur Änderung des Gesetzes über Schuljahr } \\
\text { und Schulpflicht }\end{array}$ & 09.12 .1957 & GBl. 1957,147 & Link \\
\hline BW64 & Erstfassung & $\begin{array}{l}\text { Gesetz zur Vereinheitlichung und Ordnung des } \\
\text { Schulwesens (SchVOG) }\end{array}$ & 05.05 .1964 & GBl. 1964,235 & \\
\hline BW66a & Änderung & Gesetz zur Änderung des Gesetzes zur & 29.03 .1964 & GBl. 1966,47 & Link \\
\hline BW66b & Bekanntmachung & $\begin{array}{l}\text { Vereinheitlichung und Ordnung des Schulwesens } \\
\text { Brief des Kultusministers Prof. Dr. Wilhelm } \\
\text { Hahn an die Eltern }\end{array}$ & 07.02 .1966 & Landesarchiv BW & \\
\hline \multicolumn{6}{|c|}{ 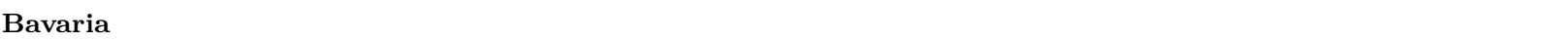 } \\
\hline BY52 & Erstfassung & Schulpflichtgesetz & 15.01 .1952 & GVBl. 1952, 11 & \\
\hline BY69 & Änderung & $\begin{array}{l}\text { Änderung des Gesetzes über die Schulpflicht } \\
\text { (Schulpflichtgesetz) }\end{array}$ & 15.04 .1969 & GVBl. 1969, 97 & \\
\hline \multicolumn{6}{|c|}{$x^{\prime}$} \\
\hline HB46 & Bekanntmachung & $\begin{array}{l}\text { Anmeldung für die Grundschule für das Schuljahr } \\
1946 / 47\end{array}$ & 16.02 .1946 & Weser Kurier & \\
\hline HB48 & Bekanntmachung & $\begin{array}{l}\text { Versorgung der Ostern } 1948 \text { in das } 1 . \text { Schuljahr } \\
\text { der Volksschule eintretenden Kinder }\end{array}$ & 04.03 .1948 & Weser Kurier & \\
\hline HB57 & Neufassung & $\begin{array}{l}\text { Gesetz über das Schulwesen der Freien Hansestadt } \\
\text { Bremen }\end{array}$ & 25.05 .1957 & GBl. 1957,57 & Link \\
\hline HB65 & Änderung & $\begin{array}{l}\text { Gesetz über die Erweiterung der Schulpflicht für } \\
\text { das Schuljahr } 1966\end{array}$ & 09.11 .1965 & GBl. 1965,137 & $\overline{\text { Link }}$ \\
\hline HB67 & Neufassung & $\begin{array}{l}\text { Bekanntmachung der Neufassung des Gesetzes } \\
\text { über das Schulwesen der Freien Hansestadt } \\
\text { Bremen }\end{array}$ & 01.06 .1967 & GBl. 1967,65 & Link \\
\hline \multicolumn{6}{|c|}{ Hamburg } \\
\hline HH41 & Bekanntmachung & $\begin{array}{l}\text { Schreiben des Schulrats an die Leitungen der } \\
\text { Mittel-, Volks-, Sonder- und Hilfsschulen: Beginn } \\
\text { des Schuljahres und der Schulpflicht }\end{array}$ & 26.03 .1941 & $\begin{array}{l}\text { Staatsarchiv HH, } \\
361-2 \text { VI, 356-10 }\end{array}$ & \\
\hline HH45 & Bekanntmachung & $\begin{array}{l}\text { Schreiben des Schulrats an die Leitungen der } \\
\text { Volks- und Mittelschulen: Verlängerung des } \\
\text { Schuljahres } 1945\end{array}$ & 02.11 .1945 & $\begin{array}{l}\text { Staatsarchiv HH, } \\
361-2 \text { VI, 356-22 }\end{array}$ & \\
\hline HH49a & Bekanntmachung & $\begin{array}{l}\text { Schreiben des Senators an die Leitungen } \\
\text { sämtlicher Schulen: Schulentlassung } 1950\end{array}$ & 27.06 .1949 & $\begin{array}{l}\text { Staatsarchiv HH, } \\
361-2 \text { VI, 356-27 }\end{array}$ & \\
\hline $\mathrm{HH} 49 \mathrm{~b}$ & Erstfassung & $\begin{array}{l}\text { Gesetz über das Schulwesen der Hansestadt } \\
\text { Hamburg }\end{array}$ & 25.10 .1949 & GVBl. 1949,257 & Link \\
\hline HH61 & Änderung & $\begin{array}{l}\text { Zweites Gesetz zur Änderung des Gesetzes } \\
\text { über das Schulwesen der Freien und Hansestadt } \\
\text { Hamburg }\end{array}$ & 03.10 .1961 & GVBl. 1961,316 & Link \\
\hline \multirow[t]{2}{*}{$\begin{array}{l}\text { HH66 } \\
\text { Hesse }\end{array}$} & Erstfassung & Schulgesetz der Freien und Hansestadt Hamburg & 09.12 .1966 & GVBl. 1966, 257 & Link \\
\hline & & & & Continued o & xt pa \\
\hline
\end{tabular}


Table B.12: Law Sources Overview (continued)

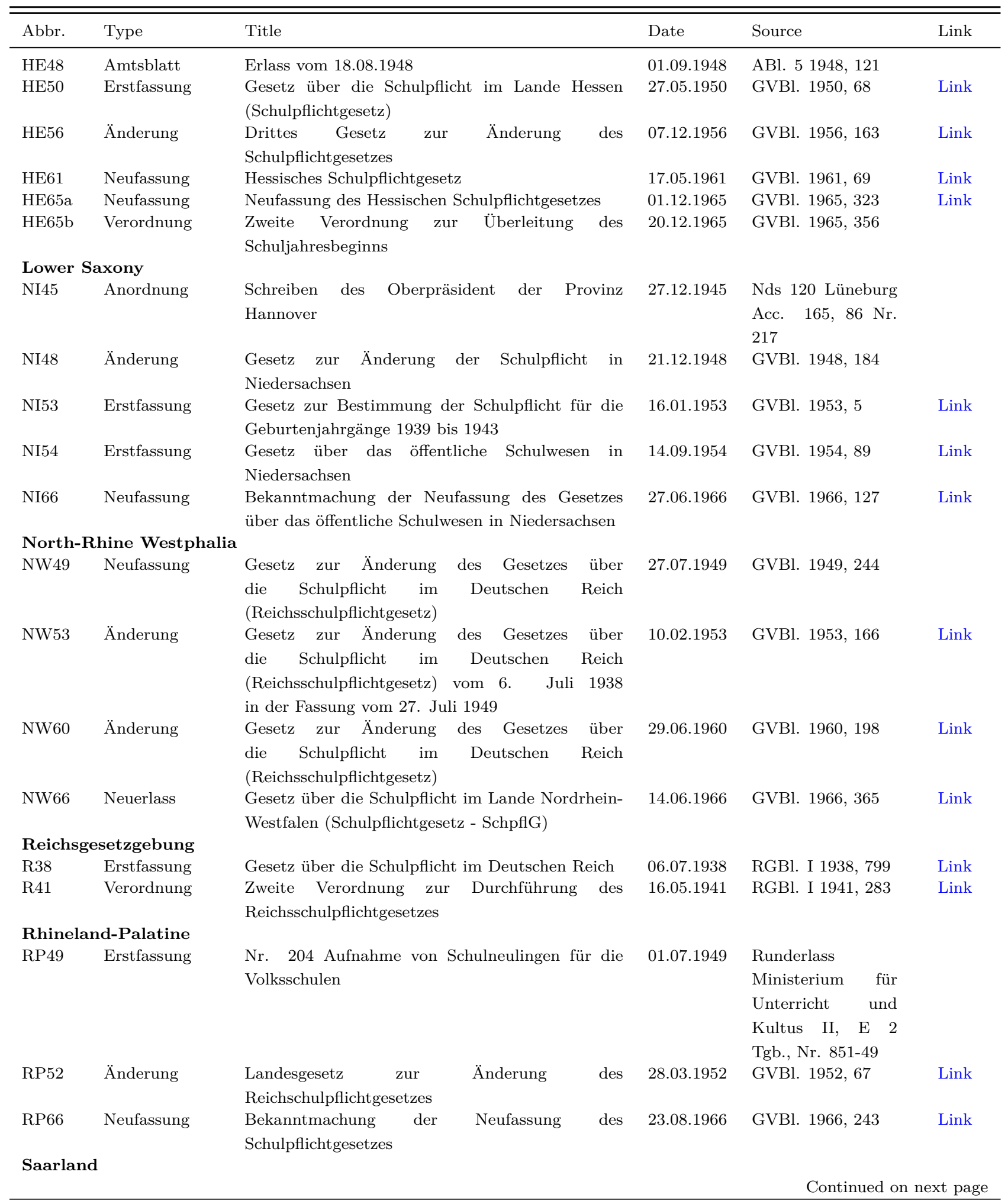


Table B.12: Law Sources Overview (continued)

\begin{tabular}{|c|c|c|c|c|c|}
\hline Abbr. & Type & Title & Date & Source & Link \\
\hline SL54 & Änderung & $\begin{array}{l}\text { Gesetz Nr. } 422 \text { zur Änderung des Gesetzes } \\
\text { über die Schulpflicht im Deutschen Reich } \\
\text { (Reichsschulpflichtgesetz) vom 6. Juli } 1938 \text { in der } \\
\text { Fassung vom 16. Mai } 1941\end{array}$ & 07.07 .1954 & ABl. 1954,831 & \\
\hline SL56 & Erlass & $\begin{array}{l}\text { Erlass des Saarländischen Ministeriums für } \\
\text { Kultus, Unterricht und Volksbildung vom } 12 . \\
\text { Juni } 1956 \text { - Beginn und Ende des Schuljahres; } \\
\text { Verlegung auf den Ostertermin }\end{array}$ & 20.06 .1956 & $\begin{array}{l}\text { Amtliches } \\
\text { Schulblatt 1956, } \\
\text { Nr.8, S.21 }\end{array}$ & \\
\hline SL58 & Änderung & $\begin{array}{l}\text { Gesetz Nr. } 621 \text { zur Änderung des Gesetzes } \\
\text { über die Schulpflicht im Deutschen Reich } \\
\text { (Reichsschulpflichtgesetz) vom 6. Juli } 1938 \text { in der } \\
\text { Fassung vom 07. Juli } 1954\end{array}$ & 14.02.1958 & ABl. 1958,297 & Link \\
\hline SL59 & Änderung & $\begin{array}{l}\text { Gesetz Nr. } 663 \text { zur Änderung des Gesetzes } \\
\text { über die Schulpflicht im Deutschen Reich } \\
\text { (Reichsschulpflichtgesetz) vom 6. Juli } 1938 \text { in der } \\
\text { Fassung vom } 14.02 .1958\end{array}$ & 06.02 .1959 & ABl. 1959,598 & Link \\
\hline SL66 & Erstfassung & $\begin{array}{l}\text { Gesetz Nr. } 826 \text { über die Schulpflicht im Saarland } \\
\text { (Schulpflichtgesetz) }\end{array}$ & 11.03 .1966 & ABl. 1966, 205 & Link \\
\hline \multicolumn{6}{|c|}{ Schleswig-Holstein } \\
\hline SH46 & Amtsblatt & Erlass des Amts für Volksbildung vom 22.7. 1946 & 22.07 .1946 & ABl. 1946,10 & \\
\hline SH47 & Erstfassung & $\begin{array}{l}\text { Gesetz betreffend die Wiedereinführung des } 9 . \\
\text { Schuljahres }\end{array}$ & 11.02.1947 & GVOBl. 1947,10 & Link \\
\hline SH55 & Erstfassung & Gesetz über die Schulpflicht & 05.12 .1955 & GVOBl. 1955, 169 & Link \\
\hline SH63 & Änderung & $\begin{array}{l}\text { Gesetz zur Änderung des Gesetzes über die } \\
\text { Schulpflicht }\end{array}$ & 25.09 .1963 & GVOBl. 1963, 115 & Link \\
\hline SH66 & Änderung & $\begin{array}{l}\text { Zweites Gesetz zur Änderung des Gesetzes über } \\
\text { die Schulpflicht }\end{array}$ & 06.04 .1966 & GVOBl. 1966,88 & Link \\
\hline
\end{tabular}

Notes: The table collects all law sources used to disentangle school-entry cut-off rules, compulsory schooling (CPS), and start of the school year reforms, either in line with the Düsseldorf Accord (DA) moving start of the school year from fall to Easter or in line with the Hamburg Accord (HA) changing the start of the school year from Easter back to fall for the birth cohorts 1935-1965 in all federal states from West Germany displayed in table B.1-table B.11 